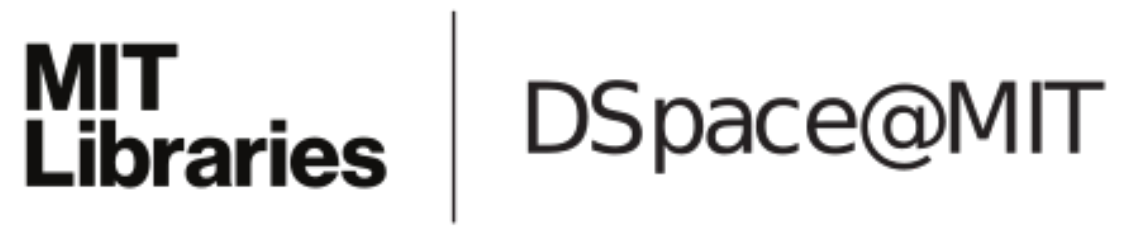

\author{
MIT Open Access Articles
}

Ice\#Shelf Meltwater Overturning in the Bellingshausen Sea

The MIT Faculty has made this article openly available. Please share how this access benefits you. Your story matters.

Citation: Ruan, X., Speer, K. G., Thompson, A. F., Schulze Chretien, L. M., \& Shoosmith, D. R. (2021). Ice-shelf meltwater overturning in the Bellingshausen Sea. Journal of Geophysical Research: Oceans, 126, e2020JC016957.

As Published: http://dx.doi.org/10.1029/2020jc016957

Publisher: American Geophysical Union (AGU)

Persistent URL: https://hdl.handle.net/1721.1/140392

Version: Author's final manuscript: final author's manuscript post peer review, without publisher's formatting or copy editing

Terms of Use: Article is made available in accordance with the publisher's policy and may be subject to US copyright law. Please refer to the publisher's site for terms of use. 


\title{
Ice-Shelf Meltwater Overturning in the Bellingshausen Sea
}

\author{
Xiaozhou Ruan ${ }^{1}$, Kevin G. Speer ${ }^{2}$, Andrew F. Thompson ${ }^{3}$, Lena M. Schulze \\ Chretien $^{4}$, Deborah R. Shoosmith ${ }^{5}$ \\ ${ }^{1}$ Department of Earth, Atmospheric, and Planetary Sciences, Massachusetts Institute of Technology, \\ Cambridge, Massachusetts \\ ${ }^{2}$ Geophysical Fluid Dynamics Institute, Department of Scientific Computing, Florida State University, \\ Tallahassee, Florida \\ ${ }^{3}$ Environmental Science and Engineering, California Institute of Technology, Pasadena, California \\ ${ }^{4}$ Marine Science Research Institute, Department of Biology and Marine Science, Jacksonville University, \\ Jacksonville, Florida \\ ${ }^{5}$ British Antarctic Survey, Cambridge, UK
}

\section{Key Points:}

- Tracer distribution over the Bellingshausen shelf is presented with data from a comprehensive hydrographic survey.

- Meltwater is present from mid-depth to surface and is accumulated toward the western shelf, consistent with a cyclonic gyre circulation.

- The inferred overturning circulation driven by ice-shelf melting is comparable to previous estimates made in the neighboring Amundsen Sea.

Corresponding author: Xiaozhou Ruan, xruan@mit.edu

This is the author manuscript accepted for publication and has undergone full peer review but has not been through the copyediting, typesetting, pagination and proofreading process, which may lead to differences between this version and the Version of Record. Please cite this article as doi: 10.1029/2020JC016957.

This article is protected by copyright. All rights reserved. 


\begin{abstract}
Hydrographic data are analyzed for the broad continental shelf of the Bellingshausen Sea, which is host to a number of rapidly-thinning ice shelves. The flow of warm Circumpolar Deep Water (CDW) onto the continental shelf is observed in the two major glaciallycarved troughs, the Belgica and Latady troughs. Using ship-based measurements of potential temperature, salinity and dissolved oxygen, collected across several coast-to-coast transects over the Bellingshausen shelf in 2007, the velocity and circulation patterns are inferred based on geostrophic balance and further constrained by the tracer and mass budgets. Meltwater was observed at the surface and at intermediate depth toward the western side of the continental shelf, collocated with inferred outflows. The maximum conversion rate from the dense CDW to lighter water masses by mixing with glacial meltwater is estimated to be $0.37 \pm 0.1 \mathrm{~Sv}$ in both depth and potential density spaces. This diapycnal overturning is comparable to previous estimates made in the neighboring Amundsen Sea, highlighting the overlooked importance of water mass modification and meltwater production associated with glacial melting in the Bellingshausen Sea.
\end{abstract}

\title{
Plain Language Summary
}

The Bellingshausen Sea is sandwiched between the Amundsen Sea and the West Antarctic Peninsula continental shelf sea and is where warm offshore waters around Antarctica can flow onto the continental shelf and directly melt the floating ice-shelves. However, in situ observations are historically very sparse in this region due to the heavy seaice cover throughout most of the year. In this study, we present the distribution of temperature, salinity, dissolved oxygen and the diagnosed meltwater concentration over the broad continental shelf of the Bellingshausen Sea from one of the most comprehensive hydrographic surveys so far. We further infer the velocity and circulation patterns by balancing the input and output rates of tracers (heat, salt and dissolved oxygen) within selected regions. A clockwise-flowing boundary current is identified over the shelf, consistent with the meltwater distribution and previous findings. Lastly, we measure the overturning circulation over the Bellingshausen Shelf, which consists of warm water inflow in the lower water column and meltwater outflow near the surface. We conclude that the magnitude of this circulation is comparable to previous estimates made in the neighboring Amundsen Sea where the ice-shelf melting has drawn much attention recently.

\section{Introduction}

West Antarctica has experienced rapid thinning of its ice shelves over much of the instrumental record (Shepherd et al., 2004; B. Smith et al., 2020; Adusumilli et al., 2020), and additional evidence suggests that the associated ice sheet mass loss has accelerated over recent decades (Rignot et al., 2019). This increased thinning has largely been attributed to the circulation of warm ocean waters under ice shelves (S. S. Jacobs et al., 1996; Jenkins et al., 2010; Pritchard et al., 2012). Particular attention has been focused on the Amundsen Sea where ice shelves such as those of Pine Island and Thwaites glaciers support large upstream catchment basins that may be grounded on retrograde topography (Joughin et al., 2012; Rignot et al., 2011), making them potentially susceptible to the marine ice sheet instability (Weertman, 1974; Thomas \& Bentley, 1978; Schoof, 2007). Marine-terminating glaciers along the coast of the West Antarctic Peninsula (WAP) have also been well studied due to the proximity of research stations and a range of longterm monitoring programs (R. C. Smith et al., 1995; Meredith \& King, 2005; Hofmann et al., 2011). The Bellingshausen Sea lies to the northeast of the Amundsen Sea along the western side of the Antarctic Peninsula, and hosts six major ice shelves: Abbot, Venable, Stange, George VI, Bach and Wilkins. These ice shelves have experienced some of the highest recorded melt rates over the past two decades in all of Antarctica (Joughin et al., 2012; Paolo et al., 2015; Adusumilli et al., 2020). However, the circulation of the 
Bellingshausen Sea and its role in connecting different regions of West Antarctica's continental shelf remains largely unstudied.

The Bellingshausen Sea is characterized by its extensive eastern boundary (Figure 1) that is able to support a geostrophically-balanced inflow from upstream along the WAP coast and an interior geostrophic flow to the west (P. Holland et al., 2010). The Bellingshausen Sea is also the location where the Antarctic Circumpolar Current (ACC) reaches its southern-most extent and where the ACC's Southern ACC Front (SACCF) and Southern Boundary (Bdy) begin to track the continental slope of the WAP (Orsi et al., 1995). Thus there is a strong interaction between the ACC and the shelf circulation in this region (P. Holland et al., 2010). The boundaries of the Bellingshausen Sea are poorly defined in the literature, often being associated with the circulation of the larger WAP. Here we focus our attention on the region that is bounded to the north and east by the deep and narrow Marguerite Trough (Figure 1). For the remainder of this paper we refer to this region as the Bellingshausen (continental) shelf. Alexander Island and the relatively shallow bathymetry surrounding it separate Marguerite Trough from the central region of the Bellingshausen Sea, where two glacially-carved troughs, the Latady and Belgica troughs (Figure 1), extend from the shelf break to the six major ice shelves in the south. These troughs deepen at their southern ends in front of the ice shelves, including the large Eltanin Bay with a maximum depth of around $1500 \mathrm{~m}$ (Figure 1). To the west, shallow bathymetry separates the Bellingshausen Sea from the easternmost trough of the Amundsen Sea (Figure 1).

The central Bellingshausen coast is populated by six major ice shelves as introduced above, in contrast to the northern region with only the northern end of George VI Ice Shelf (GVIIS). Hydrographic data shows that warm Circumpolar Deep Water (CDW) flows onto the continental shelf both through Marguerite Trough in the northern region (D. A. Smith et al., 1999; Martinson et al., 2008) and through the Belgica and Latady troughs in the southern region (Potter \& Paren, 1985; Talbot, 1988; Jenkins \& Jacobs, 2008). This CDW is likely to have access to all of the ice shelves in the Bellingshausen Sea and contributes to ice shelf mass loss through basal melting. Quantifying the relationship between ice shelf melt rates and the variability of CDW, both at the shelf break and over the continental shelf, has become a matter of great concern for predicting the stability of floating ice shelves that buttress Antarctic ice sheets and ultimately its consequences for global sea-level rise (Steig et al., 2012; Joughin et al., 2012), although these efforts have, to date, largely focused on observations and models of the Amundsen Sea (Jenkins et al., 2018; P. R. Holland et al., 2019; Kimura et al., 2016; Webber et al., 2019; Dotto et al., 2019).

The most comprehensive in situ observational analysis of ocean-forced glacial melting in the Bellingshausen Sea was carried out by Jenkins and Jacobs (2008) (hereafter JJ08) in which they derived mass, heat and freshwater fluxes from hydrographic sections across the northern and southern ends of the GVIIS cavity, including the volume transports in to and out of the ice front. Based on output from an inverse model to satisfy tracer budgets, their analysis revealed that there was a net throughflow from the southern side to the northern side of the cavity. On the southern side, 0.53 Sv flowed into the cavity with only $0.28 \mathrm{~Sv}$ flowing out; the remaining $0.25 \mathrm{~Sv}$ was determined to exit the trough at the northern end. At both the northern and southern ends of GVIIS, the outflow was concentrated in a narrow western boundary current while the inflow was more broadly spread across the sections. The inflow was focused in the deeper part of the water column with the outflow being located at both shallower depths and lighter density classes. On the southern side of the trough, a shallow outflow brought meltwater from the cavity into the southern Bellingshausen Sea at Ronne Entrance. A separate estimate of the inflow magnitude over the partial water column led to a somewhat weaker inflow $(0.32 \mathrm{~Sv})$, although several configurations of the model were considered with variable results (JJ08). 
The circulation of the Belgica and Latady troughs were inferred by Zhang et al. (2016) using observations collected by instrumented elephant seals as part of the MEOP program (Roquet et al., 2013). Using a combination of opportunistic hydrographic transects and an estimation of glacial meltwater distributions from a Gade line analysis (Gade, 1979), this study suggested that a flow towards the Bellingshausen ice shelves, comprised of Modified CDW (mCDW), a modified version of the warm CDW found offshore (Whitworth et al., 1998), occupies the eastern boundary of the Belgica Trough at depth. A boundary current along the western edge of the Belgica Trough contained meltwater in an interior layer of the water column with thickness ranging from 100 to $350 \mathrm{~m}$. This meltwater layer was also detected further to the west over the continental slope. Together these two boundary currents support a cyclonic circulation in the Belgica Trough that is sustained in part by transformation of water masses within ice shelf cavities. However, transport and meltwater fraction estimates were not provided in that study, in part due to the coarse vertical resolution of many of the seal CTD profiles. Despite these previous descriptions on the local circulation, quantitative estimates on the overturning, the diapycnal conversion of CDW to shallower and less dense layers, have been elusive in the Bellingshausen Sea.

The neighboring Amundsen Sea hosts a similar shelf-wide circulation with the presence of meltwater from ice shelves (Webber et al., 2019). The Amundsen Sea is somewhat cooler at depth $\left(\theta<1^{\circ}\right)$, though the CDW remains well above the freezing temperature of seawater, which produces extensive melting along the large ice shelves in this region (Jenkins et al., 2010; S. Jacobs et al., 2012). Previous observational studies have estimated 0.25 Sv of overturning under the Pine Island Glacier Ice Shelf cavity (S. S. Jacobs et al., 2011; Thurnherr et al., 2014), similar to that in George VI Sound. A numerical study by Webber et al. (2019) found a similar overturning strength with the strongest overturning reaching $0.38 \mathrm{~Sv}$. The analysis of Webber et al. (2019) emphasized the importance of estimating the circulation in density space. These studies document the overturning driven by the addition of meltwater and subsequent entrainment in buoyant plumes rising underneath the ice shelves.

Numerical models of flow in these ice shelf cavities represent the thermodynamics of the ice-ocean interaction at the variable pressures under the ice shelf. P. Holland et al. (2010) showed large wind-driven barotropic fluctuations of up to about $1 \mathrm{~Sv}$ through the cavity beneath the GVIIS. This corresponds to average velocities of about $5 \mathrm{~cm} \mathrm{~s}^{-1}$, larger in the narrower constrictions of the trough. Dutrieux et al. (2014) also presented numerical model results suggesting strong horizontal recirculation under the Pine Island Glacier driven by the upwelling plume, with flow of about $20 \mathrm{~cm} \mathrm{~s}^{-1}$ near the bottom. Webber et al. (2019) reported that the simulated near-bottom inflow under the PIG is higher than $50 \mathrm{~cm} \mathrm{~s}^{-1}$ averaged over the 1979-2011 period. These simulations highlight the role of both ice-cavity geometry and continental-shelf hydrographic properties on melt rates (Schodlok et al., 2012), which in turn control the distribution of the buoyancy input to dense CDW via mixing with meltwater from buoyant plumes. The total strength of the conversion of CDW to less dense layers by melting glaciers, which contributed to the "upper cell" of the global overturning circulation, is not well established. This circulation in which dense CDW becomes lighter has the opposite sense of those regions where Dense Shelf Water is produced as the precursor to Antarctic Bottom Water (AABW). However, analogous to AABW, water mass transformation over the shelf, even if relatively small, can make a significant contribution to the overturning because of entrainment with either overlying water masses or offshore waters at the shelf break. This process of entrainment amplifies relatively small diapycnal conversion rates to larger horizontal transports.

The goal of this paper is to quantify the net CDW inflow, upwelling, and subsequent outflow across hydrographic sections spanning several ice shelf termini in the Bellingshausen Sea. We use an extensive data set from 2007 that comprises several coast-to- 
coast transects that provide reasonable constraints on transports. We examine the iceshelf-driven overturning in both depth and density coordinates, which provides a link between the inflow of CDW, buoyant plume dynamics in the ice shelf cavity, and subsequent detrainment into shallower Winter Water and surface layers. Since we focus our discussion only on the continental shelf, we will refer to the warmest waters as CDW although this is a modified version $(\mathrm{mCDW})$ of the offshore CDW as introduced above. The analysis presented in this study also points to the extension of the Coastal Current (CC), established by meltwater in the northern shelf region of the West Antarctic Peninsula (Moffat et al., 2008), into the southern region of the Bellingshausen Sea (Assmann et al., 2005). We examine the strength of this current and discuss a downstream influence of the meltwater outflow near the surface in the CC.

\section{Data and regional context}

Hydrographic surveys in the Bellingshausen Sea have been historically sparse and infrequent. In this study we focus on an extensive research cruise carried out by the James Clark Ross in February and March of 2007 (JR165, Castro Morales et al., 2013). In total, the JR165 survey completed 253 conductivity-temperature-depth (CTD) profiles from the surface to the seafloor (Figure 1). The hydrographic survey was organized into a series of transects that both started and ended close to coastal boundaries. Our analysis focuses on five individual transects (Figure 1): (1) a mid-shelf section that spans both the Belgica and Latady troughs (26 stations); (2) a zonal section spanning Eltanin Bay and the front of Venable Ice Shelf (13 stations); (3) a meridional section across Latady Trough enclosing the southern boundaries of Wilkins Ice Shelf and GVIIS (17 stations); (4) a section across the base of the Latady Trough, spanning the Ronne Entrance, near the southern boundary of GVIIS (14 stations); and (5) a short zonal section in Marguerite Trough across the northern boundary of GVIIS ( 7 stations). The westernmost portion of the Bellingshausen Sea remains poorly sampled due to the presence of heavy multiyear sea-ice.

Hydrographic profiles were obtained using a Sea-Bird 911+ system (conductivity, temperature, pressure), Sea-Bird SBE 3+ and SBE 4C sensors, and an SBE-43 dissolved oxygen sensor. Further calibration and processing of the data from the JR165 cruise were discussed by Castro Morales et al. (2013). Typical station spacing varied between the transects, but did not exceed $25 \mathrm{~km}$ (except for the westernmost station pair in transect 1 ), and for transects 3,4 , and 5, the spacing was as fine as $7 \mathrm{~km}$. The local deformation radius is about $5 \mathrm{~km}$.

Interannual variability in hydrographic properties over the southern Bellingshausen Sea shelf is difficult to assess due to limited observations; however data collected in 1994 (JJ08) as well as seal-based profiles from 2008, 2009, 2010, 2013 (Zhang et al., 2016) show a similar hydrographic structure. P. Holland et al. (2010) emphasized the weaker variability in CDW properties, as compared to the Amundsen Sea shelf to the west. The Amundsen Sea is more centrally located under the Amundsen Low and therefore more strongly influenced by atmospheric variability (Thoma et al., 2008).

Seasonal variability in the water properties and the circulation of the Bellingshausen Sea have not previously been estimated from observations; however, data from instrumented seals are beginning to offer insight on these longer term variations (Pellichero et al., 2017). Mathiot et al. (2011) carried out a numerical analysis of seasonal variability of the circulation of the Antarctic margins, which was dominated by a fall and winter intensification of the Antarctic Slope Front over the continental slope. The sea surface height (SSH) product developed by Armitage et al. (2018) for ice-covered regions of the Southern Ocean shows similar seasonal fluctuations and also provides supporting evidence for a cyclonic circulation over the Bellingshausen shelf, although in situ obser- 
vations indicate that circulation features typically have scales smaller than those resolved by the SSH data.

\section{Hydrography}

Hydrographic properties along the five primary CTD transects from JR165 (Figure 1) are strongly influenced by the major bathymetric features of the shelf, which organize the circulation into a series of boundary or frontal currents that dominate the onshore and offshore transport. Key water masses include warm $\left(\theta>1^{\circ} \mathrm{C}\right)$ and salty $(S>$ 34.5) $\mathrm{CDW}$, cold $\left(\theta<-1.5^{\circ} \mathrm{C}\right)$ Winter Water $(\mathrm{WW})$ and surface water masses with varying temperature and salinity due to the direct impact of atmospheric forcing (Figure 2).

Warm CDW is found along the Latady and Belgica troughs in transect 1 (Figure 3a), accompanied by a dissolved oxygen concentration minimum (Figure 3c). The warmest CDW core appears in the Belgica Trough, suggesting a major inflow pathway onto the Bellinghausen Sea shelf. The salinity maximum, on the other hand, has been eroded and is not easily identifiable in this section (Figure $3 \mathrm{~b}$ ). The maximum temperature of the $\mathrm{CDW}$ drops from $1.5^{\circ} \mathrm{C}$ in the Belgica Trough at transect 1 to $1.2^{\circ} \mathrm{C}$ closer to the ice shelf faces (transects 2, 3 and 4), suggesting some mixing of water masses during the transit from shelf break to ice shelf cavity. Consistent with the cyclonic circulation over the Bellingshausen shelf, transects 3 and 4 (Figure 4d-i) both show CDW flowing towards the GVIIS at depth for the profiles on the eastern side of each transect. Both transects also exhibit significant tilting of density surfaces or isopycnals at shallower depth on the west. Transect 2 spans both the Venable Ice Shelf (referred to as transect $2 \mathrm{~W}$ later) and the deep Eltanin Basin (referred to as transect 2E) where the doming isopycnals indicate a cyclonic gyre circulation within the basin (Figure 4a-c). Oxygen concentrations within the Eltanin Basin are lower compared to the upstream transects 3 and 4 (Figure 4c), suggesting recirculation within the basin. Finally, transect 5 within Marguerite Trough to the north of the GVIIS does not show a signature of WW (the minimum temperature is above $-1^{\circ} \mathrm{C}$; Figure $3 \mathrm{~d}$ ). Thus, rather than having a mixture of CDW, WW and meltwater, transect 5 indicates a direct mixing/conversion of the CDW and meltwater, consistent with the observations made by JJ08.

To address the distribution of meltwater over the shelf, we follow a similar analysis to JJ08, using the tracers $\theta$ (potential temperature), $\mathrm{S}$ and $\mathrm{O}_{2}$, to quantify the location and concentration of glacial meltwater in the water column. The analysis used is similar to the "Gade line" calculation (Gade, 1979) for a two-component mixture between the meltwater and CDW, but differs due to our consideration of meltwater mixing in a non-uniform environment. Here, the meltwater mixes with both CDW and WW. This approach requires defining end members in various tracer spaces; mixing lines between these end members are compared to measured values to determine the relative contribution of each end member in a given observation. The selection of these end members is discussed in detail in Biddle et al. (2017). Here, for simplicity, we choose end members with properties that are characteristic of a water mass over a broad spatial region. We provide a detailed discussion of hydrographic transect 1 as an illustrative example.

We define three end members: $\operatorname{CDW}\left(\theta=1^{\circ} \mathrm{C} ; \mathrm{S}=34.7 ; \mathrm{O}_{2}=4 \mathrm{ml} \mathrm{kg}^{-1}\right)$, WW $\left(\theta=-1.7^{\circ} \mathrm{C} ; \mathrm{S}=34 ; \mathrm{O}_{2}=6.5 \mathrm{ml} \mathrm{kg}^{-1}\right)$ and meltwater $\left(\theta=-89^{\circ} \mathrm{C} ; \mathrm{S}=0 ; \mathrm{O}_{2}=24\right.$ $\left.\mathrm{ml} \mathrm{kg}^{-1}\right)$. The meltwater properties were determined in JJ08 by assuming zero salinity and accounting for the latent heat needed to melt the ice. The high oxygen concentration reflects the air trapped in voids in the ice. We adopt the same values here due to the similarity of the study regions.

The tracer plots can be used to determine bounds on meltwater fraction. For instance, properties that are colder and fresher along the blue dashed curve in Figure 5b 
indicate progressively greater contributions of meltwater (black dashed contours). The maximum meltwater fraction is determined by the intersection with the freezing point, taken here to be evaluated at surface pressure. The upper limit of the meltwater fraction is thus $3.1 \%$, and we remove estimated meltwater concentrations higher than the upper limit in all transects.

Considering transect 1 , the distributions of meltwater using different tracer pairs $\left(\theta / \mathrm{S}, \mathrm{O}_{2} / \mathrm{S}\right.$ and $\left.\mathrm{O}_{2} / \theta\right)$ shows some quantitative differences. The largest discrepancy between estimates of meltwater concentration occurs within the surface layer (shallower than $200 \mathrm{~m}$ ). Both the $\theta / \mathrm{S}$ and $\mathrm{O}_{2} / \mathrm{S}$ estimates (Figure $5 \mathrm{a}, \mathrm{b}$ ) suggest high meltwater concentration near the surface, whereas the $\mathrm{O}_{2} / \theta$ estimate primarily shows a subsurface signature of the meltwater (Figure 5c). These differences arise due to the influence of surface forcing (heat/freshwater fluxes) that breaks the tracer conservation assumption near the surface. We choose to use the $\mathrm{O}_{2} / \mathrm{S}$ meltwater fraction estimate for the remaining transects as the best indicator of both a subsurface signal and reasonable (non-zero and within the upper limit) values of meltwater near the surface. Note, however, that in the tracer budgets considered later, the meltwater concentration in the surface layer is not included due to the larger uncertainty associated with meltwater estimates near the surface.

For transect 1 , subsurface meltwater concentrations peak at roughly $1 \%$. The meltwater concentration is largest along the western side of the section (Figure 5b), which is consistent with previous finding in Zhang et al. (2016). Transect 2 shows the inflow and outflow of meltwater from upstream in the Eltanin Bay (Figure 6a), and the subsection in front of the Venable Ice Shelf indicates high meltwater concentration $(>0.5 \%)$ in the upper $300 \mathrm{~m}$. The distribution of meltwater in the Venable subsection is similar to that in transect 5 where direct mixing between CDW and glacial meltwater is present (Figure 6b). Despite the strong surface meltwater signal, both transects 3 and 4 show a consistent accumulation of meltwater on the western side of the sections, indicating potential meltwater outflows.

\section{Estimated velocity and overturning under the ice shelves}

Both the hydrographic properties and the meltwater fractions suggest modification of the warm CDW on the shelf that could be related to the lateral circulations in the troughs and an overturning in density space. Next, we calculate the geostrophic velocity distribution along each transect to constrain the magnitude of this overturning. Our approach is to use the thermal wind relationship and to select a level of no motion based on balancing tracer and mass budgets as outlined in JJ08. The JR165 cruise did acquire direct velocity observations from the underway shipboard acoustic Doppler current profiler (SADCP), however, these velocities are dominated by large instantaneous barotropic components. Our focus here is on the mean overturning circulation that is largely due to the baroclinic component of the flow rather than the barotropic component. We thus focus on the baroclinic component except, as discussed in more detail below, where the SADCP data is applied to assess the magnitude of the barotropic gyre recirculation in the Eltanin Basin.

\subsection{Geostrophic velocity and transport estimates}

As a comparison with JJ08, we first assess the throughflow beneath GVIIS and compare to the measurements collected in 1994. We adopt a "telescoping" approach by using transport estimates from the innermost sections to initialize our analysss on subsequent sections and, in this way, move progressively towards the shelf break to arrive at a balanced circulation for the entire shelf. 
Based on the RTopo v2 bathymetry product (Schaffer \& Timmermann, 2016), a sill under GVIIS with a depth of $550 \mathrm{~m}$ is located at $70^{\circ} 30^{\prime} \mathrm{S}$, and a local maximum in ice shelf draft (BEDMAP, Fretwell et al., 2013) close to $400 \mathrm{~m}$ depth is present near $72^{\circ} \mathrm{S}$. P. Holland et al. (2010) suggested that the mean throughflow under GVIIS is roughly $0.1 \mathrm{~Sv}$; the instantaneous signal is variable and may reach a maximum amplitude of roughly $\pm 1 \mathrm{~Sv}$, or $\pm 0.05 \mathrm{~m} \mathrm{~s}^{-1}$ from their assumed cross-sectional area. The adjustment timescale of their wind-driven flow reversal is roughly 2 weeks, such that a typical horizontal water displacement would peak at $100 \mathrm{~km}$, or only about a third of the length of GVIIS. JJ08 inferred a net throughflow of $0.17-0.27 \mathrm{~Sv}$ based on property distributions and geostrophic velocities.

We also infer a negligibly weak net throughflow under GVIIS, as the sill located near 70 30'S serves to partially block deeper CDW and mix deep properties on the northern side of the trough (figure not shown), consistent with P. Holland et al. (2010). An ice shelf draft of $250 \mathrm{~m}$ close to the sill blocks shallower layers. Wind-driven variability will have a tendency to advect CDW up and over this sill, which is likely to generate enhanced mixing with overlying waters containing glacial melt (Venables et al., 2017).

A choice of reference level is required to produce horizontal transport estimates. We considered a level of no motion at either $300 \mathrm{~m}$ based on the meltwater distribution (transect 1, 2W and 5), similar to the $0.5 \%$ meltwater concentration choice by JJ08, or a bottom reference level (transect $2 \mathrm{E}, 3$ and 4 ). These choices both produce a reasonable circulation with inflow on the eastern side and outflow on the western side of both the northern and southern transects that bound the GVIIS cavity and over the broader Bellingshausen continental shelf (Figure 7). The barotropic transport in section 1 is smaller than those found in the outer shelf and shelf break region of the Bellingshausen Sea (Schulze Chretien et al., 2021), implying that our study region is likely to be shielded from a wind forcing response concentrated near the shelf break. Overall, the sense of the general circulation is consistent with a larger-scale cyclonic flow associated with the Antarctic Coastal Current (Moffat et al., 2008). Enhanced meltwater concentrations (>0.5\%) are found on the western side of each section, in agreement with this cyclonic flow.

The westernmost station pairs in both transects $2 \mathrm{~W}$ and $2 \mathrm{E}$ required additional adjustments to satisfy several constraints. Specifically, a $0.1 \mathrm{~m} \mathrm{~s}^{-1}$ barotropic velocity was added to the two westernmost station pairs in both subsections. Without this barotropic component, the outflow on the shallow western end of transect $2 \mathrm{~W}$ is negligible, which is inconsistent with the observed meltwater distribution. The outflow magnitude is determined by comparing with the cross-section velocity among the westernmost stations in transect 1, considering the proximity of these stations. Meltwater transported from upstream and produced locally in front of the Venable Ice Shelf flows in and out of transect $2 \mathrm{~W}$ and is ultimately exported on the western end of transect 1 . A similar outflow magnitude has been reported under the PIG cavity (S. S. Jacobs et al., 2011; Webber et al., 2019). Transect $2 \mathrm{E}$ is influenced by the gyre circulation in Eltanin Basin, which is greater than $1000 \mathrm{~m}$ deep. We assume that the circulation in this basin will respond to local atmospheric forcing (the wind stress curl) on closed geostrophic contours, and the total transport may be poorly represented by the mean thermal wind shear, similar to localized gyre circulation reported in front of the PIG (Webber et al., 2017). Therefore, for transect 2E, we turned to the SADCP data from JR165 as a supplementary confirmation of the velocity field in this region. The SADCP data show a recirculation in the Eltanin Basin of roughly 1.2 Sv, similar to the reported 1.5 Sv transport for the winddriven recirculation gyre in the Pine Island Bay (Thurnherr et al., 2014). Thus, based on the SADCP measurements, a background velocity of $0.1 \mathrm{~m} \mathrm{~s}^{-1}$ was added to the westernmost station pair so that the magnitude of the barotropic transport roughly matches that estimated from the SADCP data. Finally, a small (magnitudes less than $0.005 \mathrm{~m}$ $\mathrm{s}^{-1}$ in all cases), uniform velocity was added to each section (from sea surface to seabed) to ensure that the section-integrated transport is zero to satisfy mass conservation. To- 
gether, these choices provide initial transport estimates that are then used as input for the inverse model.

\subsection{Inverse model}

Construction of the initial velocity field is based on the observed tracer distributions. The velocity estimates are then further refined by employing a minimum length inverse analysis (Wunsch, 1978) to satisfy both mass and tracer conservation over the $n$ station pairs of interest. Mass and tracer balances provide the following constraints:

$$
\begin{gathered}
\sum_{j=1}^{n}\left(M_{\mathrm{out}}-M_{\mathrm{in}}\right)_{j}=M_{\mathrm{melt}} \\
\sum_{j=1}^{n}\left[(M \chi)_{\mathrm{out}}-(M \chi)_{\mathrm{in}}\right]_{j}=M_{\mathrm{melt}} \chi_{\mathrm{melt}}
\end{gathered}
$$

where $M$ is mass transport and $\chi$ denotes the property of the tracer. The subscript "melt" refers to the value of tracer $\chi$ associated with meltwater added to the water column. Combining (1) and (2), we arrive at the following relationship after eliminating the unknown meltwater transport,

$$
\begin{aligned}
\sum_{j=1}^{n}\left\{\left[M\left(\chi-\chi_{\text {melt }}\right)\right]_{\text {out }}-\right. & {\left.\left[M\left(\chi-\chi_{\text {melt }}\right)\right]_{\text {in }}\right\}_{j}=} \\
& \frac{1}{g} \sum_{j=1}^{n}\left\{\int_{P_{\text {bot }}}^{P_{\text {top }}} v(p)\left[\chi(p)-\chi_{\text {melt }}\right] \Delta x(p) \mathrm{d} p\right\}_{j}=0 .
\end{aligned}
$$

Here $p$ is pressure $\left(P_{\mathrm{bot}}\right.$ and $P_{\text {top }}$ denote the bottom and top most pressure levels within each station pair) and $\Delta x$ is the horizontal separation for each station pair. This separation is constant with depth except in bottom triangle regions where $\Delta x$ decreases linearly to 0 . We also extrapolate the velocity in the bottom triangles by linearly reducing it to 0 from the values at the deepest common levels between neighboring stations. Other techniques for extrapolating velocities into the bottom triangles had little quantitative impact on the following results (not shown).

Finally, the reference velocities in each station pair are determined from inverting:

$$
\mathbf{A v}+\mathbf{b}=0
$$

where:

$$
\begin{gathered}
A_{i j}=\frac{1}{g}\left\{\int_{P_{\mathrm{bot}}}^{P_{\mathrm{top}}}\left[\chi_{i}(p)-\chi_{\text {melt }}\right] \Delta x(p) \mathrm{d} p\right\}_{j}, \\
b_{i}=\frac{1}{g} \sum_{j=1}^{n}\left\{\int_{P_{\mathrm{bot}}}^{P_{\mathrm{top}}} v_{\mathrm{rel}}(p)\left[\chi_{i}(p)-\chi_{\mathrm{melt}}\right] \Delta x(p) \mathrm{d} p\right\}_{j},
\end{gathered}
$$

and

$$
v_{j}=\left(v_{\text {ref }}\right)_{j} .
$$

Thus, the total velocity $v(p)$ is decomposed into the known relative velocity $v_{\text {rel }}(p)$, supplied from the initial velocity field, and the reference velocity $v_{\text {ref }}$ in each station pair. The reference velocities provide adjustments to balance mass and tracer budgets based on the initial velocity input.

Equations (5)-(8) are solved with a minimum length approach since the system is under-determined, i.e. the number of the tracers $\left(\theta, \mathrm{S}\right.$ and $\left.\mathrm{O}_{2}\right)$ is less than the number of station pairs. Technically there are infinite number of solutions associated with this under-determined system. The velocity field that arises from the solution must satisfy 
mass and tracer conservation, and is chosen to be the closest to the initial input velocity distribution. As a final step, the weighted minimum length solution, proposed by Wunsch (1978), is applied. This approach addresses the case of uneven CTD sampling by preferentially applying adjustments to larger station separations.

This is achieved using:

$$
\mathbf{v}=\mathbf{W}^{-1} \mathbf{A}^{T}\left(\mathbf{A} \mathbf{W}^{-1} \mathbf{A}^{T}\right)^{-1}(-\mathbf{b}),
$$

where $\mathbf{W}$ is given by:

$$
W_{j j}=\frac{1}{g}\left[\int_{P_{\mathrm{bot}}}^{P_{\mathrm{top}}} \Delta x(p) \mathrm{d} p\right]_{j},
$$

and the double $j$ index refers to the diagnonal position in matrix $W$.

As discussed above, we employ a "telescoping" approach in which velocities from sections located closest to GVIIS are used to initialize sections sequentially offshore. We define control volumes following JJ08 using transects 4 and 5 , followed by transects 3 and 5, assuming there is no throughflow under GVIIS (see section 4.1). After calculating the velocity output in transects 3,4 and 5, we apply the inverse model in transects 1 and 2 individually, assuming there is no net loss/gain of mass or other tracers across the broad Bellingshausen shelf and from coast to coast in front of the Eltanin Basin and Venable Ice Shelf.

We choose to balance the tracer budgets $\left(\theta, \mathrm{S}\right.$ and $\left.\mathrm{O}_{2}\right)$ below $200 \mathrm{~m}$, or that part of the water column that is not directly affected by tracer sources and sinks at the oceanatmosphere boundary. This also imposes a condition of no net volume transport below $200 \mathrm{~m}$. The final velocity distribution is shown in Figure 8. The qualitative pattern of the geostrophic velocity field is similar to the initial distribution, however, substantial adjustments are made with the constraints of mass and tracer conservation. For instance, in almost all sections that use $300 \mathrm{~m}$ as the reference level of no motion, outflows are now present below $300 \mathrm{~m}$ compared with the initial distribution. This change is a reflection of the local CDW circulation at depth, and further reduces the amplitude of the overturning. Alternative choices for balancing the mass/tracer budgets across the sections were investigated using the inverse model. We obtained solutions for (i) conservation of both mass and tracer from surface to bottom, and (ii) conservation of only mass from surface to bottom, but conservation of tracer below $200 \mathrm{~m}$. However, these choices yield an overturning that is inconsistent with a warm water inflow in the lower part of the water column and meltwater outflow in the upper part of the water column (Thompson et al., 2020).

A small net mass imbalance occurs when integrating the velocity field throughout the water column (Figure 9), which can arise, for instance, due to wind-driven Ekman transport. A final barotropic adjustment (from surface to seafloor) was applied to each transect (detailed in the next section) to satisfy section-wide mass conservation (Figure 9). This adjustment leaves the baroclinic overturning essentially unaffected. For section 1 , the offset was $1.7 \times 10^{-3} \mathrm{~m} \mathrm{~s}^{-1}$, equivalent to about $0.5 \mathrm{~Sv}$ of transport, which is roughly in agreement with Ekman transport estimated from the climatological wind stress aligned with the section. In all sections, the offset was very small, $O(1) \mathrm{mm} \mathrm{s}^{-1}$, or roughly two orders of magnitude smaller than the geostrophic velocities. An Ekman transport can also be applied to the mass conservation equation of the inverse model (e.g., Wunsch et al., 1983), but we lack reliable in situ wind stress measurements and thus fall back on the method described above. We note that a similar approach was used in Lumpkin et al. (2008). 


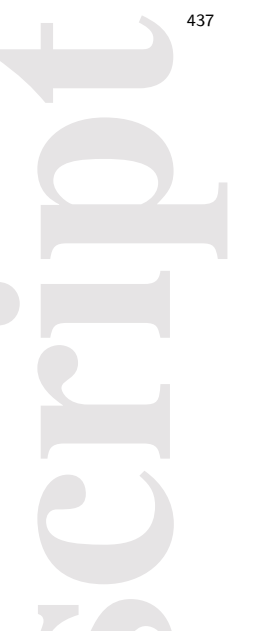

\subsection{Ice-shelf overturning circulation}

We calculated the overturning streamfunctions across each hydrographic section by vertically and horizontally integrating the total velocity across the section:

$$
\Psi(z)=\int_{-H(x)}^{z} \int_{x_{W}}^{x_{E}} v\left(x, z^{\prime}\right) \mathrm{d} x \mathrm{~d} z^{\prime},
$$

where $z^{\prime}$ is a dummy variable, $x$ is the along-section distance and $x_{W}$ and $x_{E}$ are the zonal limits of the section, $-H(x)$ is the depth of the seafloor, and $v$ is the cross-section velocity output from the inverse model. Transport in bottom triangles is also included in the integral. The final overturning streamfunctions across each section are a sum of the integral in equation (11) from the seafloor to the sea surface and an additional contribution to balance the surface Ekman transport: $\Psi_{\text {total }}=\Psi+\psi$ where $\psi$ is calculated by integrating the barotropic offset. Similarly, the overturning streamfunction in potential density space is defined as:

$$
\Psi(\rho)=\int_{\rho_{\mid z=-H}}^{\rho_{\mid z}} \int_{x_{W}}^{x_{E}} v(x, \rho) \mathrm{d} x \mathrm{~d} \rho \frac{\mathrm{d} z}{\mathrm{~d} \rho},
$$

where the thickness in the target density layer is calculated as $\mathrm{d} \rho \frac{\mathrm{d} z}{\mathrm{~d}}$. Error in the overturning calculations is estimated by modifying the reference velocities in the initial guess by $20 \%$ (shading in Figure 10). This is essentially a barotropic adjustment of the water column that over most of the section has little effect on the overturning. A change to the reference velocity over shallow topography near the boundaries can produce significant modifications to the section-wide overturning because this directly affects the vertical structure of the horizontally-integrated transport. Traditionally, uncertainty associated with an inverse analysis is assessed by prescribing covariances based on existing observations, such as a repeat hydrography or moored time series of velocity measurements (Lumpkin et al., 2008). However, due to extremely sparse observations in this region, this approach is not possible. Lacking long-term in situ velocity measurements, we chose a $20 \%$ variation in the reference velocity as plausible error of the mean velocity in our initial guess. Other choices have been tested but they do not change the result qualitatively. Overall, upwelling, or the transformation from heavier to lighter density classes, reaches a maximum near $200 \mathrm{~m}$ depth $\left(\sigma_{0}=27.56 \mathrm{~kg} \mathrm{~m}^{-3}\right)$. Here, the total overturning streamfunction peaks at $\sim 0.37 \mathrm{~Sv}$. Overturning across transect 1 roughly agrees with the sum of overturning cells closer to the ice shelves (transects 2 and 3).

The shape of the overturning profile is related to the interior and boundary fluxes of buoyancy. A number of ice shelves exist south of transect 1 and meltwater is expected to be distributed over a wide range of depth or density. The overturning maximizes near $200 \mathrm{~m}$ depth overall, corresponding to the maximum upwelling. This agrees with the typical depth of the intermediate meltwater maximum (Figures 5 and 6). In density space, the location of the maximum overturning corresponds to the transformation of CDW to a glacially-modified version of CDW, which may have properties that are similar to Winter Water. All the overturning profiles show a broad concentration of inflow from about 200-400 m depth and outflow above $200 \mathrm{~m}$. Transects 4 and 5, south and north of GVIIS respectively, show a change in the form of the overturning near the sill depth $(550 \mathrm{~m})$ and maximum draft depth $(400 \mathrm{~m})$ (Figure 10). This change is consistent with a reduction in outflow on the northern side of GVIIS, across the depths spanning the sill depth and the maximum draft under GVIIS. On the southern side of GVIIS, the outflow increases more rapidly above the sill depth.

\section{Discussion}

\subsection{Comparison to Amundsen Sea overturning}

An important feature of the hydrographic sections analyzed in this study is that they all are "closed" sections that extend from coast to coast, including a few across ma- 
jor ice-shelf fronts. The coast-to-coast structure of the surveys enables us to make reasonable assumptions with regard to tracer and volume transports that, in turn, constrain the overturning. We find that CDW is converted to lighter water masses over a range of densities at a rate of about $0.37 \pm 0.1 \mathrm{~Sv}$. This is, to our knowledge, the first estimate of a density-based overturning circulation in the Bellingshausen Sea, although similar analyses have been carried out in the Amundsen Sea, where over the past two decades, there has been a substantially larger number of field programs.

The overturning rate in the Bellingshausen Sea is comparable to that estimated near the Pine Island and Thwaites glaciers in the Amundsen Sea. Using a numerical model, Webber et al. (2019) estimated 0.38 Sv overturning in front of Pine Island and Thwaites ice shelf cavities and $0.25 \mathrm{~Sv}$ overturning in the Pine Island cavity itself, comparable to previous observational estimates (S. S. Jacobs et al., 2011; Thurnherr et al., 2014). Although the overall overturning rate in the Amundsen Sea is almost certainly higher when accounting for other major ice shelves, the dynamics controlling the transport of warm CDW onto the continental shelf are likely similar in both the Amundsen and Bellingshausen seas. The temperature of CDW on the shelf, the thickness of the CDW layer, and the areal extent of CDW-ice shelf interactions are also comparable. If we use a straightforward relationship between the melt rate and overturning strength as shown in Joughin et al. (2012), the fact that the total melt rate in the Amundsen Sea is almost twice that in the Bellingshausen Sea (Rignot et al., 2013; Adusumilli et al., 2020) suggests a total overturning rate of $O(1) \mathrm{Sv}$ when these two regional seas are combined.

Destabilization of ice shelves in the Amundsen Sea will have a greater impact on sea level rise than the Bellingshausen Sea because they buttress larger ice sheets. However, water mass transformation in the ice shelf cavities occurs in both continental seas, and the associated freshwater input have significant implications for the global overturning circulation: the lightening of CDW through the injection of glacial meltwater is a significant component of the Southern Ocean's "upper" overturning cell (Marshall \& Speer, 2012). While lightening occurring in the upper cell is typically associated with surface heating or sea ice melt (Abernathey et al., 2016), shelf processes can also have a strong impact through entrainment that occurs at the ice shelf front (Naveira Garabato et al., 2017), over the shelf, and at the shelf break. This "clockwise" overturning (assuming south is to the left) is a nearly ubiquitous feature of the Antarctic margins, even when the exchange of CDW on to the shelf is relatively weak, e.g. Filchner-Ronne. However, elsewhere additional shelf transformation processes, such as brine rejection and the formation of High Salinity Shelf Water, convert the lighter Ice Shelf Water into Dense Shelf Water (DSW) that eventually becomes AABW (Nicholls et al., 2009). Thus, in terms of ocean circulation, processes occurring in the Bellingshausen and Amundsen seas should be considered in assessing future changes to the large-scale circulation, especially in response to modifications in atmospheric forcing.

In both regions, the flow towards and away from the ice shelves is topographically steered by large glacially-carved troughs (Webber et al., 2019). These troughs support cyclonic circulations where CDW flows southward along the trough's eastern boundary (Zhang et al., 2016; Webber et al., 2019). This focusing of the circulation relieves some of the challenges of collecting closed transects across the shelf.

\subsection{Extension of the coastal current across West Antarctica}

The coastal current (CC) that flows southward over the WAP shelf (Moffat et al., 2008 ) is intimately linked to the overturning. The CC signal is present across multiple measurements of moored ADCP from Adelaide Island to Alexander Island and is typically within several tens of kilometers of the coast (Moffat et al., 2008). The core of the CC has been found to collocate with a salinity front created mainly by freshwater input from local glacial melt (Moffat et al., 2008). Thus, the CC system is continuously sup- 
ported by input from the overturning cell along its path. The local overturning circulation in the Bellingshausen Sea that converts warm CDW into light meltwater in the ice cavities supplies buoyancy to the $\mathrm{CC}$ and therefore is directly linked to the horizontal CC transport.

This positive correlation among the local ice shelf melting, ice-cavity overturning, and the transport over the shelf has been confirmed in numerical simulations. Jourdain et al. (2017) showed that $45 \%$ of the CC's barotropic transport along the coast of the Amundsen Sea can be attributed to horizontal pressure gradients induced by meltwater. The meltwater-induced horizontal pressure gradient leads to a local acceleration of the westward flow through the thermal wind relationship and a corresponding adjustment of the sea surface height. We expect a similar situation in the Bellingshausen Sea.

It is well established that around $10 \mathrm{~Sv}$ of CDW gets incorporated into dense AABW around Antarctica and subsequently sinks to the ocean abyss in the lower cell of the global meridional overturning circulation (Lumpkin \& Speer, 2007; Talley, 2013; Purkey \& Johnson, 2013). The other $10 \mathrm{~Sv}$ is transformed into the light surface water masses and returned to lower latitudes in the upper cell (Marshall \& Speer, 2012). In addition, the meltwater-driven $\mathrm{CC}$ relates to the water mass transformation in both directions. First, the direct conversion from CDW to lighter waters under the ice shelves should be treated as an additional branch of the upper MOC on the continental shelves of Antarctica; we estimate the conversion rate to be around $O(1) \mathrm{Sv}$ in the ice cavities of the Amundsen and Bellingshausen seas and possibly more outside of the cavities due to entrainment on their way out to the open ocean. Second, the CC carries meltwater downstream to the coastal polynyas (adjacent to the coast, fast ice or ice shelves) where around $5 \mathrm{~Sv}$ of the DSW is formed around Antarctica (Orsi et al., 2002) and the freshwater input could locally shut off the deep convection and thus DSW formation. Thus, the CC, together with its formation and downstream influence in a warming climate needs to be assessed more closely around the coast of Antarctica.

\subsection{Impact beyond the Bellingshausen Sea}

Our analyses indicate that processes in the Bellingshausen Sea modify warm CDW that enters through the Belgica and Latady troughs and the relatively fresh CC arriving from the WAP to the northeast of the Bellingshausen Sea. The export of these modified waters from the Bellingshausen Sea could influence the larger-scale circulation of West Antarctica (Nakayama et al., 2014). The hydrographic sections from JR165 largely confirm the interior shelf circulation structure inferred from seal data by Zhang et al. (2016), in particular that outflow from the Bellingshausen Sea is largely confined to the shelf break at the western boundary of the Belgica Trough. Transport pathways as determined from a research cruise in January 2019 are also similar (Thompson et al., 2020). The properties of the shelf break in the western Bellingshausen Sea are noteworthy due to the confluence of the ACC's southern boundary and the Ross Gyre's eastern boundary (Roach \& Speer, 2019), supporting a region of enhanced lateral shear that is likely to contribute to both the dispersion and mixing of water properties.

While observations in the region between the Bellingshausen and Amundsen seas are sparse, there is strong numerical evidence that these waters are transported to the west. Nakayama et al. (2014) and Nakayama et al. (2018) carried out tracer release experiments in high resolution simulations of the circulation in West Antarctica. In particular, water sourced from Bellingshausen Sea ice shelves had both eastward and westward flowing components at the shelf break, the westernmost Bellingshausen Sea continental shelf and almost all of the Amundsen Sea's continental shelf received contributions from this melt water (Figure 2 in Nakayama et al. (2014)). Interestingly, all meltwaters sourced from Amundsen Sea ice shelves, in this simulation, flow westward and make relatively small contributions to the easternmost trough that feeds Pine Island Glacier. 
Previous studies have argued that CDW entering the Amundsen Sea's easternmost trough is sourced from the west, but it seems reasonable that this water is mixed with water containing a significant fraction of meltwater from the Bellingshausen Sea. In this way, processes occurring in the Bellingshausen Sea may provide additional feedbacks on water flowing within the Pine Island Glacier and Thwaites ice shelf cavities.

\section{Conclusions}

We analyzed an extensive hydrographic survey collected in the Bellingshausen Sea to produce estimates of the overturning circulation for the first time in the region. The magnitude of the overturning circulation reaches $0.37 \pm 0.1 \mathrm{~Sv}$ over the Bellingshausen Sea continental shelf and is comparable to the previously documented overturning in the neighboring Amundsen Sea Embayment. The overturning circulation is dominated by contributions from basal melting of six major ice shelves in the southern Bellingshausen Sea. Although ice shelf melting in the Amundsen Sea is likely to have a greater impact on sea level rise than the Bellingshausen Sea, the transformation of CDW into lighter density classes through the injection of glacial meltwater in both continental seas forms a significant, extreme branch of the Southern Ocean's upper cell, closing the innermost part of the upper cell that reaches onto the shelf and into the ice cavities.

These hydrographic sections also capture the inflow of a narrow coastal current that develops from glacial melt input along the coast of the WAP. This flow receives the upwelled, glacially-modified CDW exiting ice shelf cavities and transports these new water mass properties to the western limits of the Bellingshausen Sea. From there it is likely to influence the frontal structure of the boundary currents over the continental slope that connects the Bellingshausen and Amundsen seas. The ability of these waters, modified in the Bellingshausen Sea, to reach the Amundsen Sea and influence water properties there constitutes an important link between the two embayments.

\section{Acknowledgments}

We thank Laurence Padman for his detailed and insightful comments that improved the presentation of the manuscript. XR and AFT were supported by NSF OPP-1644172. KS acknowledges support from NSF OPP-1643679 and NSF OCE-1658479. Data from JR165 are archived at the British Oceanography Data Centre (https://www.bodc.ac.uk/data/documents/cruise/8529/).

\section{References}

Abernathey, R. P., Cerovecki, I., Holland, P. R., Newsom, E., Mazloff, M., \& Talley, L. D. (2016). Water-mass transformation by sea ice in the upper branch of the Southern Ocean overturning. Nat. Geosci., 9(8), 596.

Adusumilli, S., Fricker, H. A., Medley, B., Padman, L., \& Siegfried, M. R. $\quad$ (2020). Interannual variations in meltwater input to the southern ocean from antarctic ice shelves. Nature geoscience, 13(9), 616-620.

Armitage, T. W., Kwok, R., Thompson, A. F., \& Cunningham, G. (2018). Dynamic topography and sea level anomalies of the Southern Ocean: Variability and teleconnections. J. Geophys. Res. Oceans, 123, 613-630.

Assmann, K. M., Hellmer, H. H., \& Jacobs, S. S. (2005). Amundsen sea ice production and transport. Journal of Geophysical Research: Oceans, $110(\mathrm{C} 12)$.

Biddle, L. C., Heywood, K. J., Kaiser, J., \& Jenkins, A. (2017). Glacial meltwater identification in the Amundsen Sea. Journal of Physical Oceanography, 47(4), 933-954.

Castro Morales, K., Cassar, N., Shoosmith, D. R., \& Kaiser, J. (2013). Biological production in the Bellingshausen Sea from oxygen-to-argon ratios and oxygen triple isotopes. Biogeosciences, 10(4), 2273-2291. 


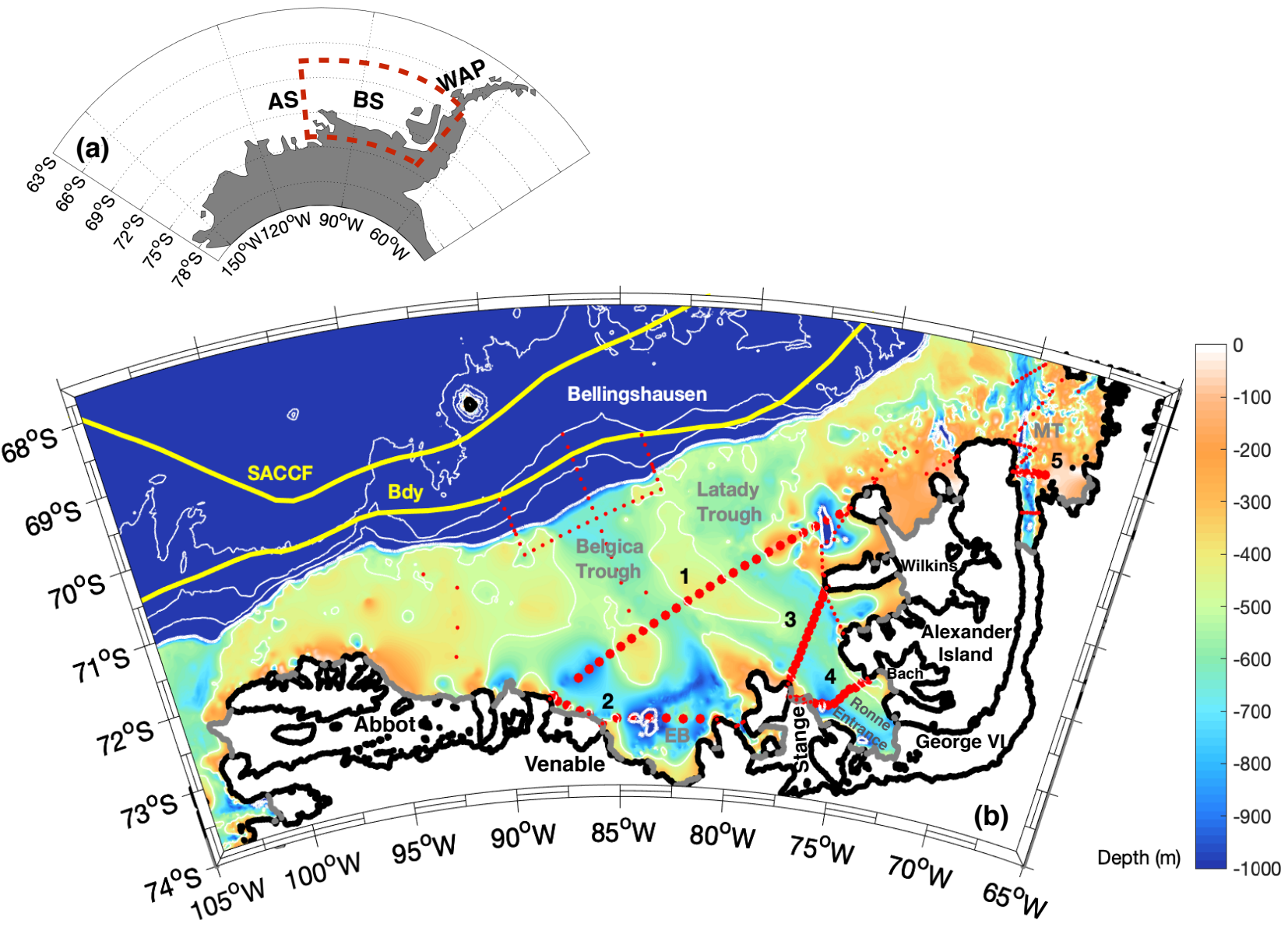

Figure 1. Overview of the study region. (a) The Bellingshausen Sea (BS), Amundsen Sea (AS) and Western Antarctic Peninsula (WAP) in the Southern Ocean. (b) Enlarged map of the red box in panel (a) with bathymetry from the RTopo-2 (Schaffer \& Timmermann, 2016) product given in color. Over the shelf, the 500 and $1000 \mathrm{~m}$ isobaths are contoured in white; offshore the contour interval is $1000 \mathrm{~m}$. The red dots show the CTD stations from the JR165 cruise. The enlarged red dots represent the CTD stations used in this study with transect numbers indicated. The thick black and gray contours delineate the coast and ice shelf fronts, respectively. The names of the major ice shelves are provided. The two yellow lines represent the climatological positions of the Southern ACC front (SACCF) and the southern boundary of the ACC (Bdy) as defined in (Orsi et al., 1995). EB and MT are abbreviations for the Eltanin Basin and Marguerite Trough.

This article is protected by copyright. All rights reserved. 


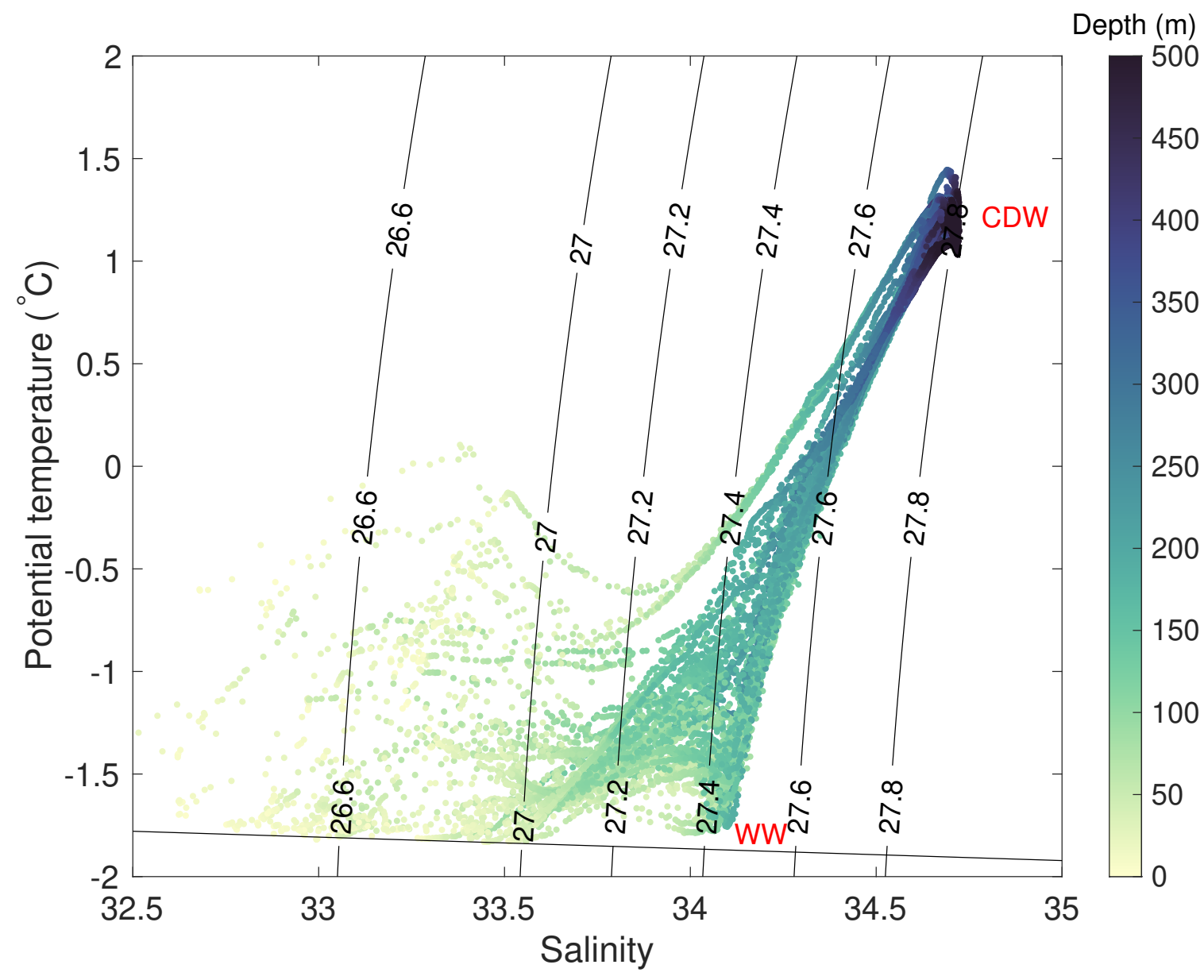

Figure 2. The $\theta / \mathrm{S}$ (potential temperature and practical salinity) diagram for measurements from transects 1-5 in this study. Each measurement is colored by its depth. Contours are potential density referenced to the surface. The near-horizontal solid line indicates the surface freezing point. CDW and WW are abbreviations for Circumpolar Deep Water and Winter Water. 

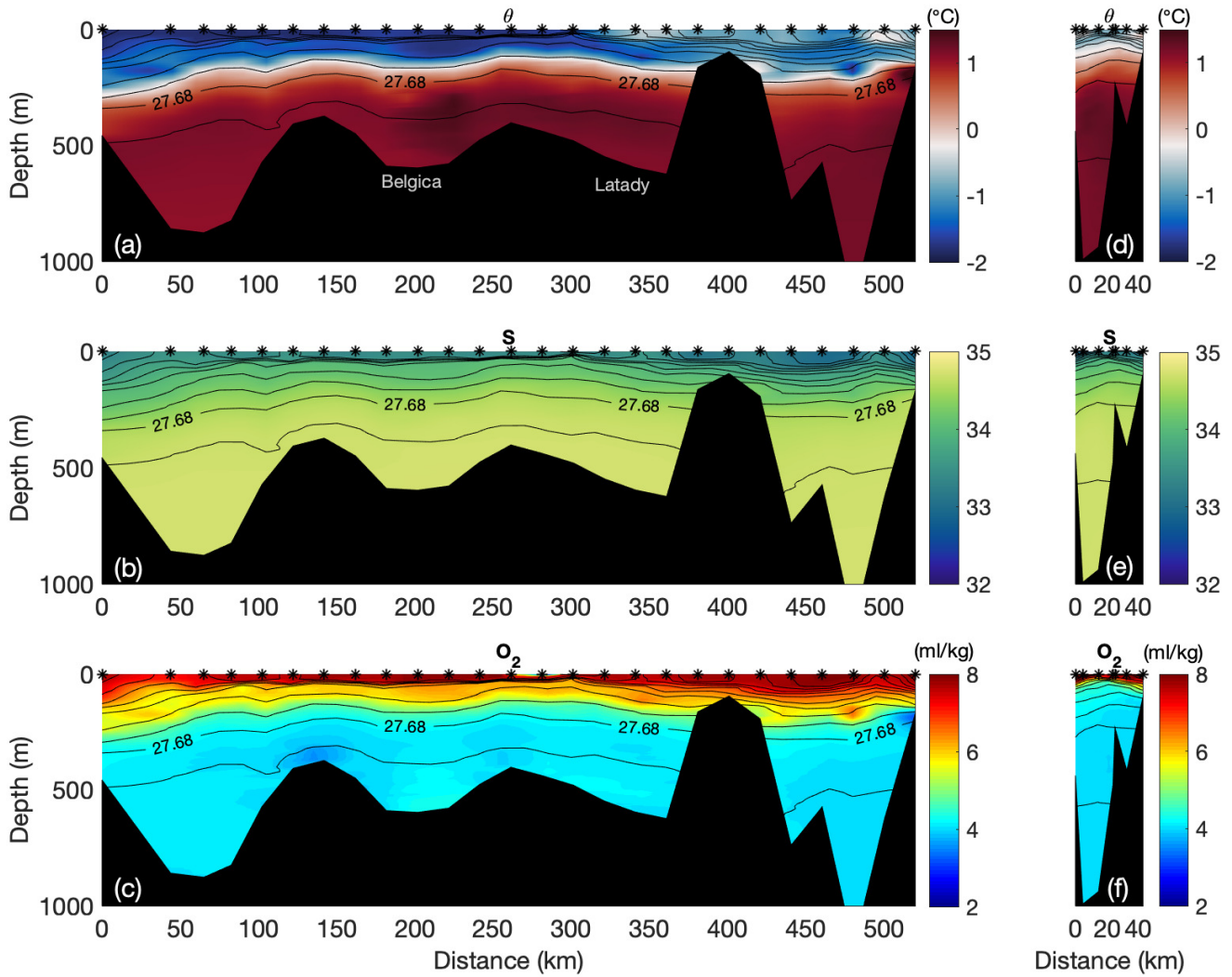

Figure 3. The distribution of potential temperature (a, d), salinity (b, e) and dissolved oxygen $(\mathrm{c}, \mathrm{f})$ for transects 1 (left) and 5 (right); the position of these sections are shown in Figure 1. The black contours denote potential density contours $\left(0.12 \mathrm{~kg} \mathrm{~m}^{-3}\right.$ intervals $)$ and the black stars at the top of each panel represent the station locations. The center of the Belgica and Latady troughs are labeled. All the transect plots are from west to east throughout the paper.

This article is protected by copyright. All rights reserved. 

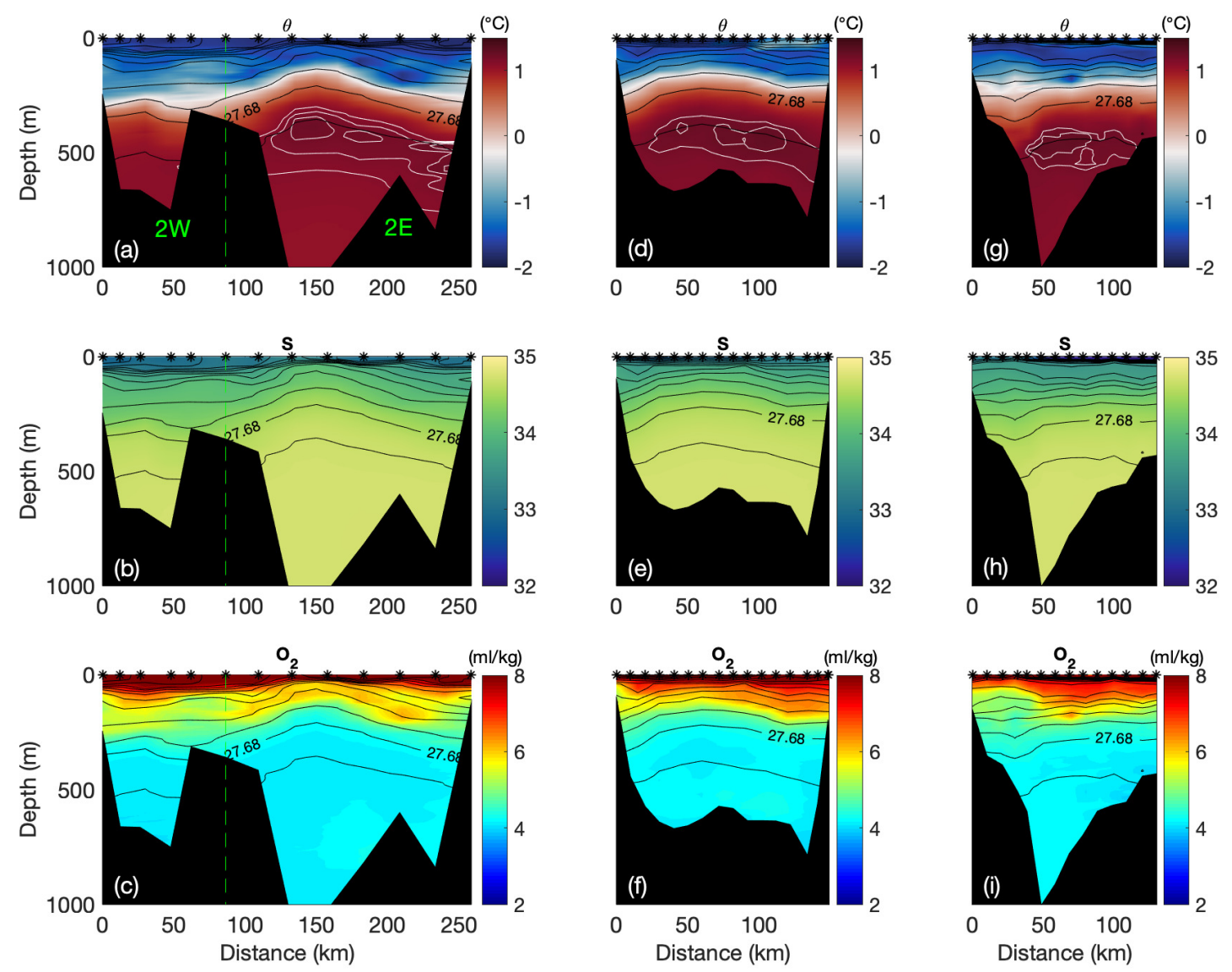

Figure 4. The distribution of potential temperature (a, d, g), salinity (b, e, h) and dissolved oxygen (c, f, i) for transect 2 (left), 3 (middle) and 4 (right); the position of these sections are shown in Figure 1. The black contours denote potential density contours $\left(0.12 \mathrm{~kg} \mathrm{~m}^{-3}\right.$ intervals) and the black stars at the top of each panel represent the station locations. High potential temperature values are contoured in white with an interval of $0.05^{\circ} \mathrm{C}$. The boundary between transects $2 \mathrm{~W}$ and $2 \mathrm{E}$ are marked by the vertical dashed green line (a-c).

This article is protected by copyright. All rights reserved. 

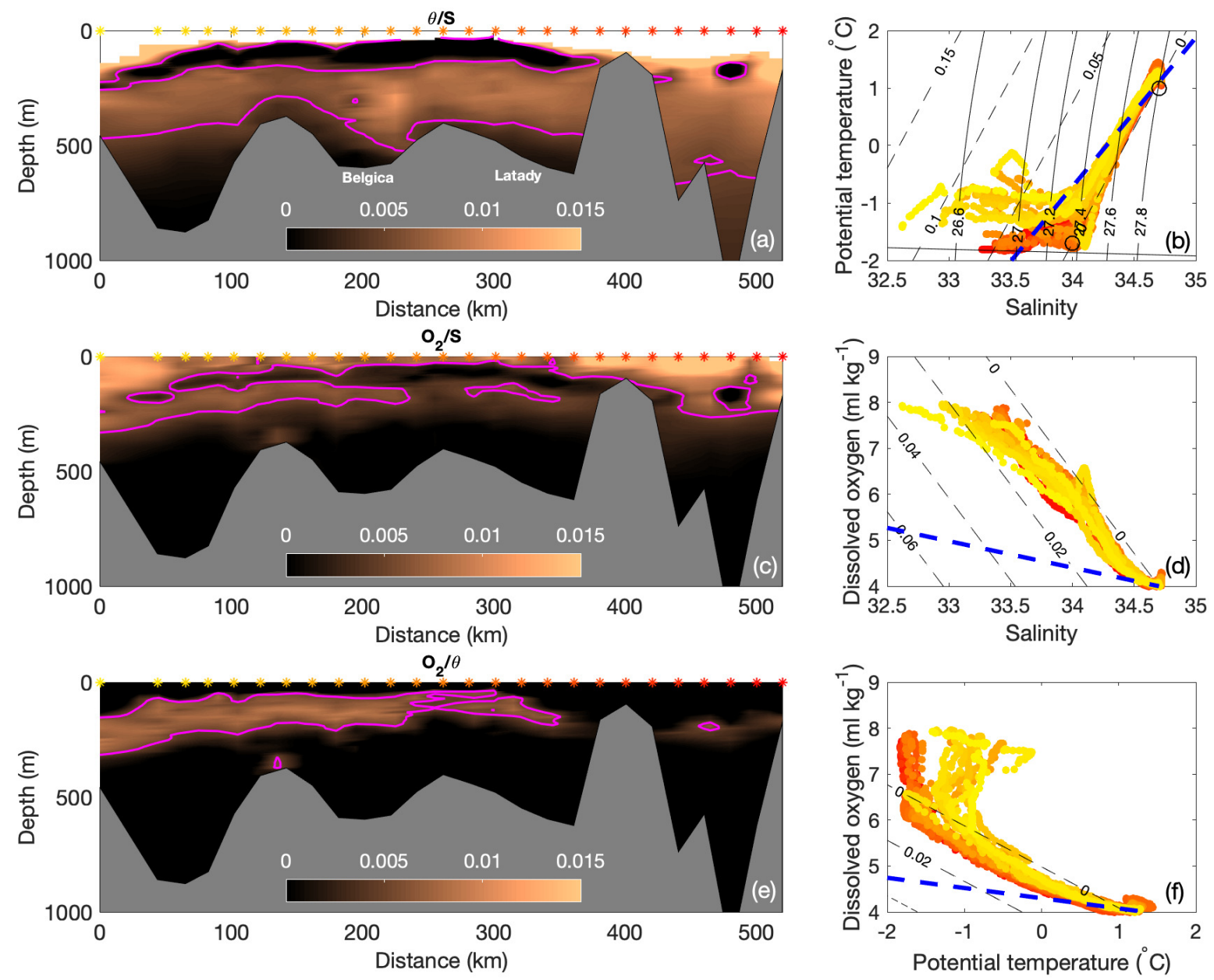

Figure 5. The meltwater distribution in transect 1 and the corresponding property pair. The meltwater distribution calculated using potential temperature/salinity (a), dissolved oxygen/salinity (c), and dissolved oxygen/potential temperature (e) with the corresponding property pair shown in (b), (d), (f). The magenta contour in (a), (c), (e) denotes the $0.5 \%$ meltwater concentration. The black dashed lines in (b), (d), (f) represent the meltwater concentration. The blue dashed lines represent the two-member mixing between the CDW and meltwater. The thin black lines in (b) are potential density referenced to the surface. The near-horizontal solid line denotes the surface freezing point. The colors in (b), (d), (f) are consistent with those of different station locations indicated at the top of (a), (c), (e). 

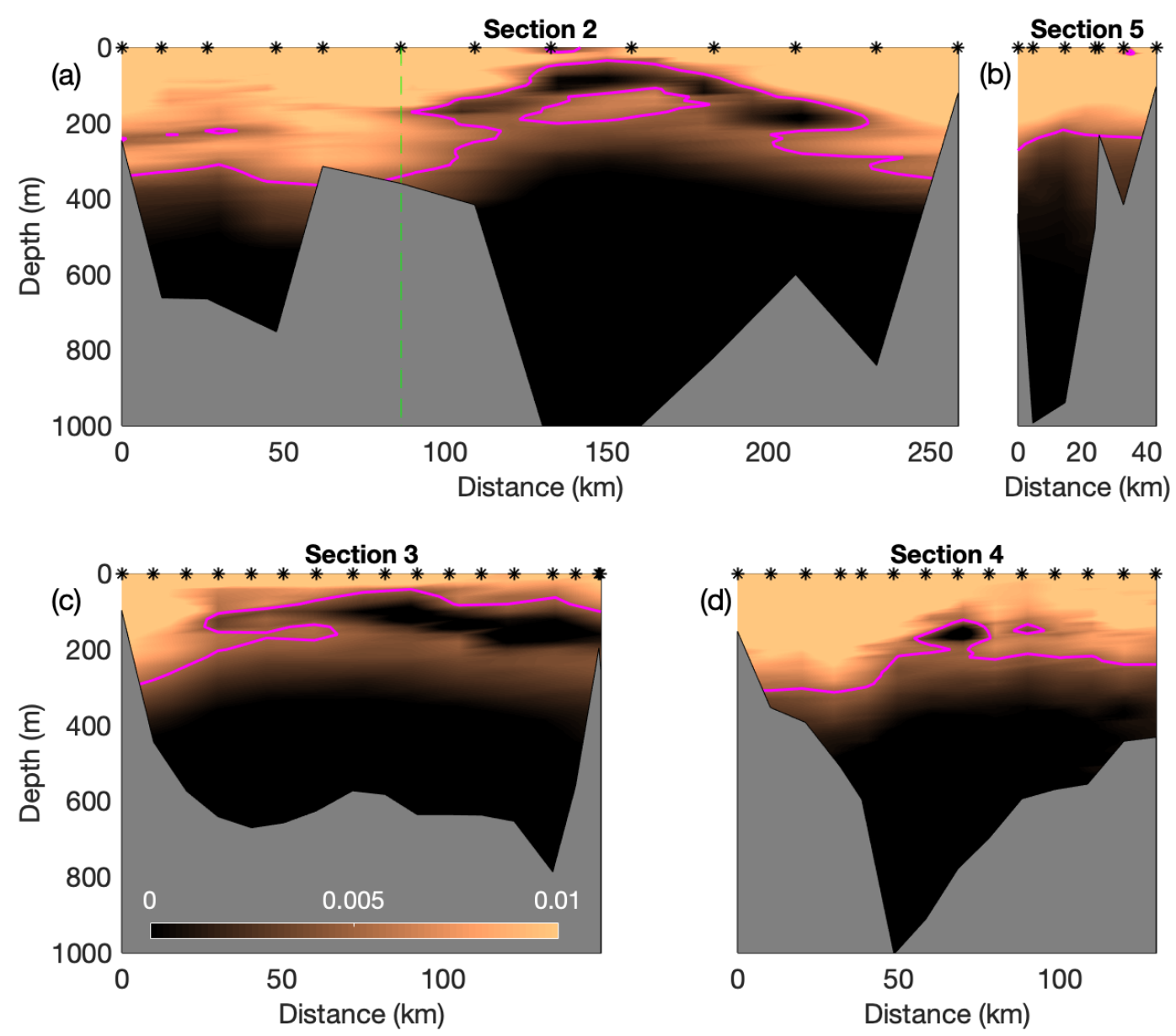

Figure 6. The meltwater distribution in transect 2-5 calculated using oxygen/salinity. The magenta contour denotes the $0.5 \%$ meltwater concentration. The black stars at the top of each panel represent the station locations. The boundary between transects $2 \mathrm{~W}$ and $2 \mathrm{E}$ are marked by the vertical dashed green line in (a).

This article is protected by copyright. All rights reserved. 

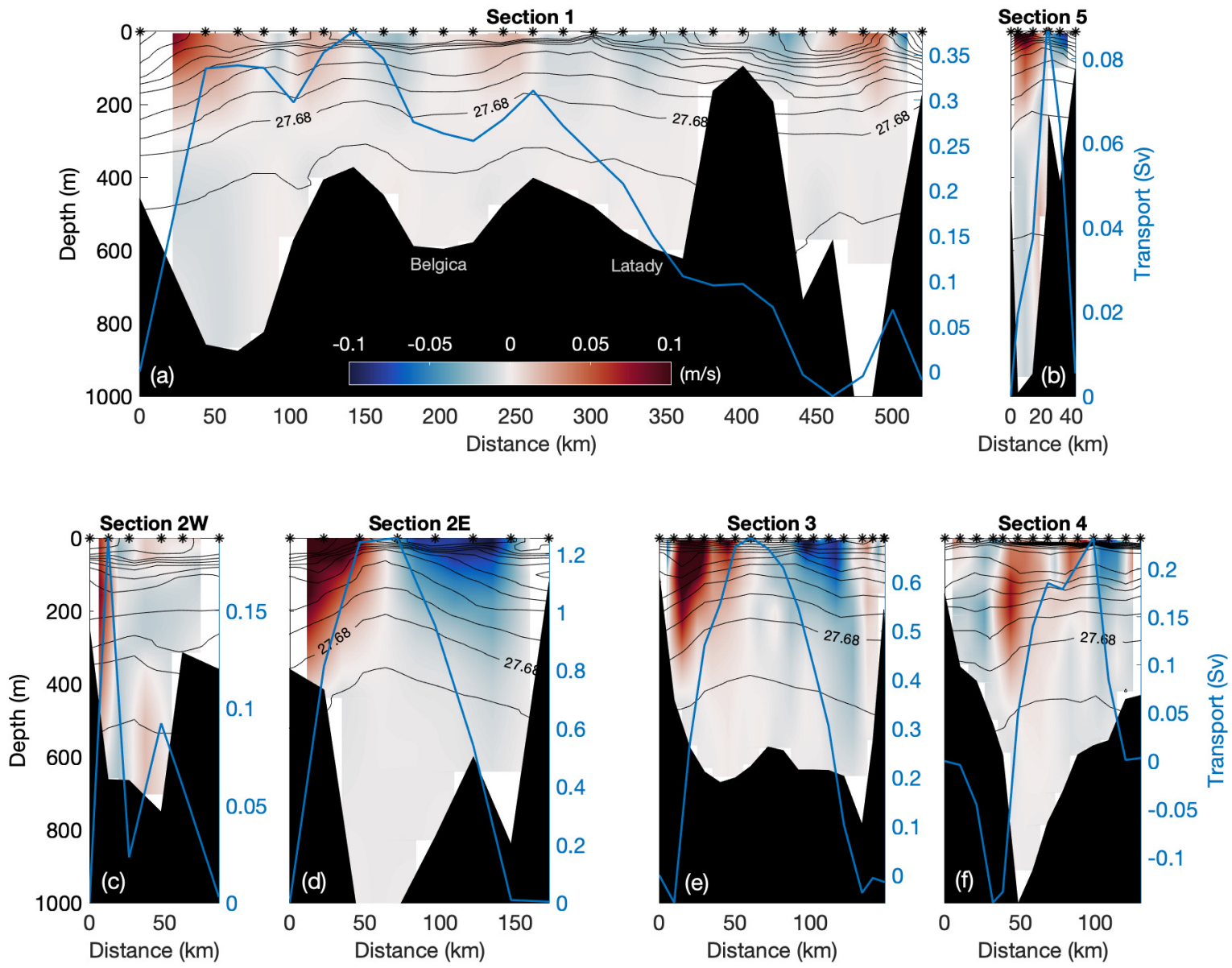

Figure 7. Geostrophic velocity $\left(\mathrm{m} \mathrm{s}^{-1}\right)$ distribution across various sections shown in Figure 1 , based on initial guesses and with bottom triangles filled. Red and blue indicate off-shore and shoreward flows, respectively. The black contours are potential density referenced to the surface and the intervals are $0.12 \mathrm{~kg} \mathrm{~m}^{-3}$. The blue line represents the cumulative transport, starting from the west, in units of Sv. The black stars at the top of each panel represent the station locations.

This article is protected by copyright. All rights reserved. 

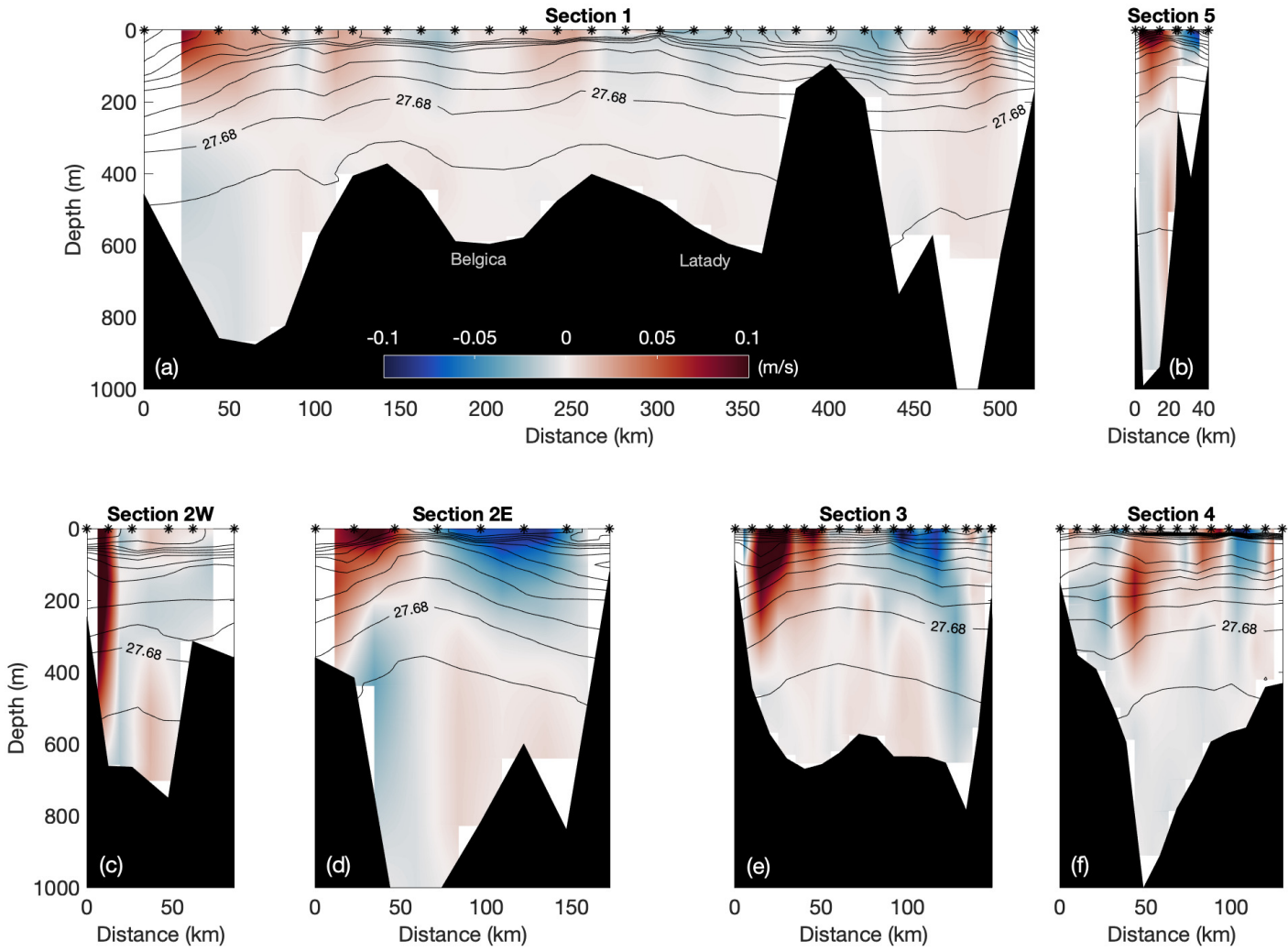

Figure 8. Geostrophic velocity $\left(\mathrm{m} \mathrm{s}^{-1}\right)$ distribution as in Figure 7, but following the inverse modeling. Red and blue indicate off-shore and shoreward flows, respectively. The black contours are potential density referenced to the surface and the intervals are $0.12 \mathrm{~kg} \mathrm{~m}^{-3}$. The black stars at the top of each panel represent the station locations.

This article is protected by copyright. All rights reserved. 


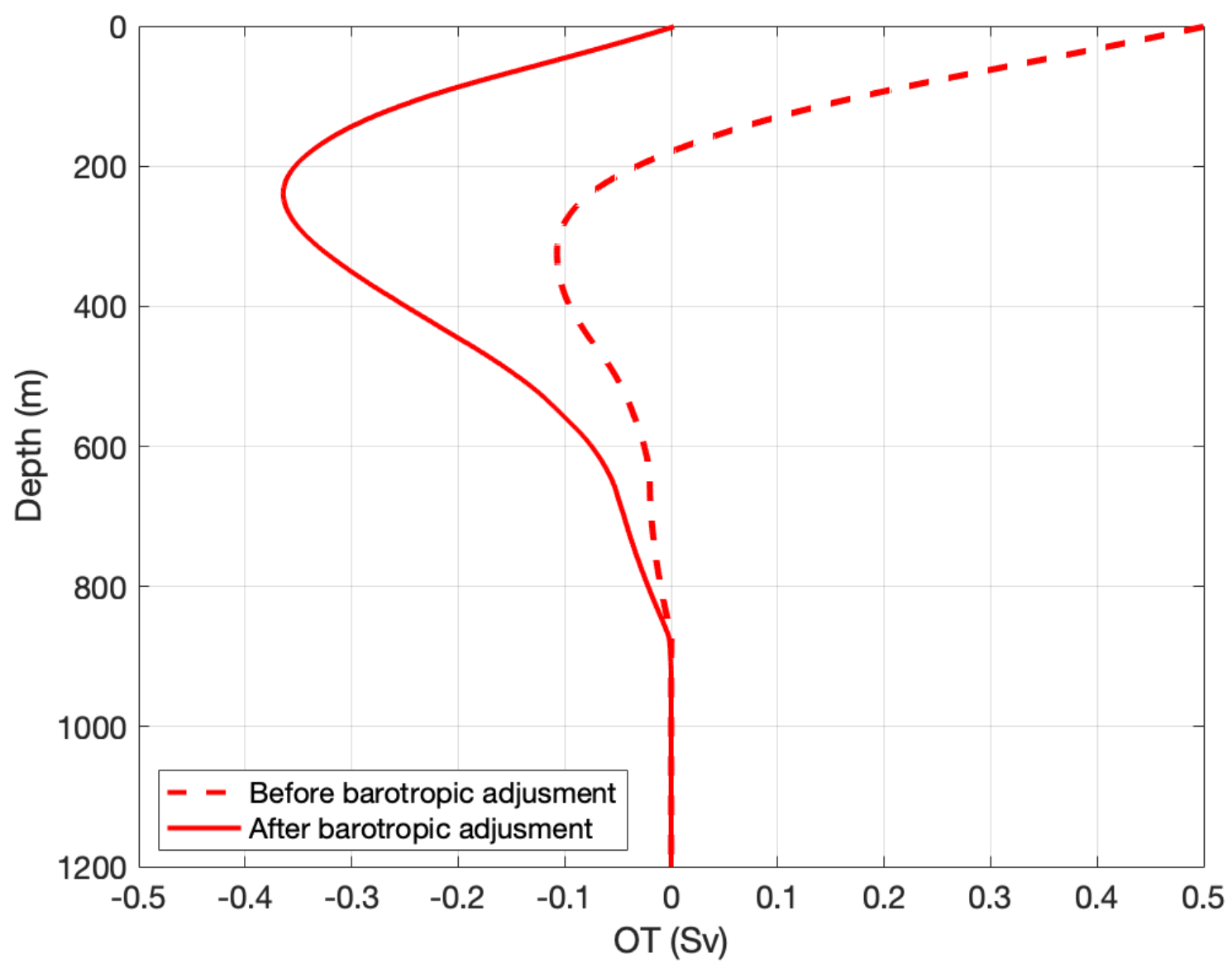

Figure 9. The overturning streamfunction for transect 1 in depth space before and after the barotropic adjustment to account for the mass imbalance due to wind-driven Ekman transport.

This article is protected by copyright. All rights reserved. 

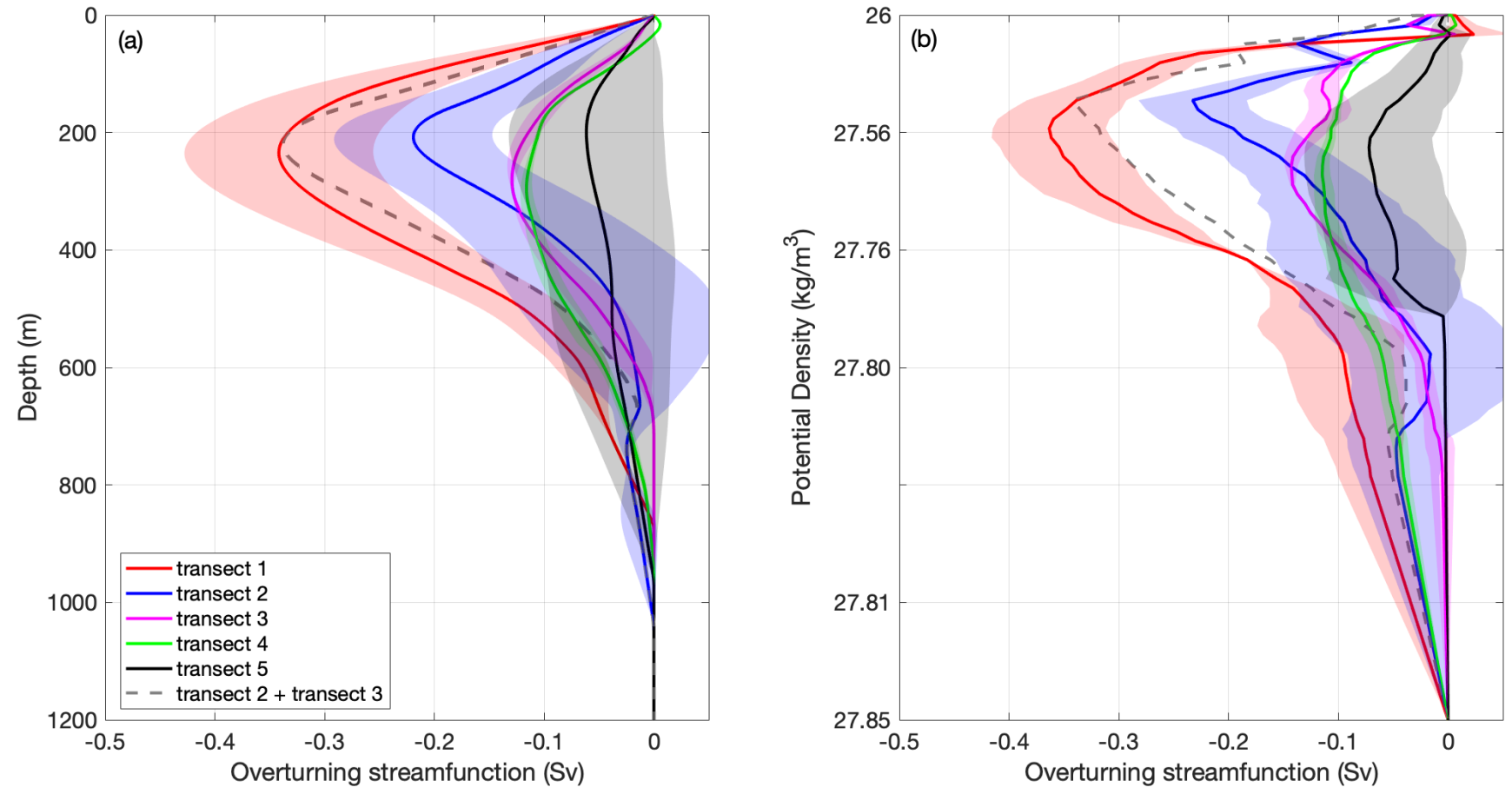

Figure 10. The overturning streamfunction for each section in depth (a) and potential density (b) coordinates; the position of the sections are shown in Figure 1. Shadings denote error bounds for $80 \%$ and $120 \%$ of the reference velocity for each section. 
Dotto, T. S., Naveira Garabato, A. C., Bacon, S., Holland, P. R., Kimura, S., Firing, Y. L., ... Jenkins, A. (2019). Wind-driven processes controlling oceanic heat delivery to the Amundsen Sea, Antarctica. Journal of Physical Oceanography, 49(11), 2829-2849.

Dutrieux, P., De Rydt, J., Jenkins, A., Holland, P. R., Ha, H. K., Lee, S. H., ... Schröder, M. (2014). Strong sensitivity of Pine Island ice-shelf melting to climatic variability. Science, 343(6167), 174-178.

Fretwell, P., Pritchard, H. D., Vaughan, D. G., Bamber, J. L., Barrand, N., Bell, R., ... others (2013). Bedmap2: improved ice bed, surface and thickness datasets for Antarctica.

Gade, H. G. (1979). Melting of ice in sea water: A primitive model with application to the antarctic ice shelf and icebergs. Journal of Physical Oceanography, 9(1), $189-198$.

Hofmann, E. E., Klinck, J. M., Costa, D. P., Daly, K. L., \& Torres, J. J. (2011). The us southern ocean global ocean ecosystems dynamics program. Oceanography, $15(2)$.

Holland, P., Jenkins, A., \& Holland, D. M. (2010). Ice and ocean processes in the Bellingshausen Sea, Antarctica. J. Geophys. Res., 115.

Holland, P. R., Bracegirdle, T. J., Dutrieux, P., Jenkins, A., \& Steig, E. J. (2019). West Antarctic ice loss influenced by internal climate variability and anthropogenic forcing. Nature Geoscience, 12(9), 718-724.

Jacobs, S., Jenkins, A., Hellmer, H., Giulivi, C., Nitsche, F., Huber, B., \& Guerrero, R. (2012). The Amundsen sea and the Antarctic ice sheet. Oceanography, $25(3), 154-163$.

Jacobs, S. S., Hellmer, H. H., \& Jenkins, A. (1996). Antarctic ice sheet melting in the Southeast Pacific. Geophys. Res. Lett., 23(9), 957-960.

Jacobs, S. S., Jenkins, A., Giulivi, C. F., \& Dutrieux, P. (2011). Stronger ocean circulation and increased melting under Pine Island Glacier ice shelf. Nat. Geosci., 4(8), 519-523.

Jenkins, A., Dutrieux, P., Jacobs, S. S., McPhail, S. D., Perrett, J. R., Webb, A. T., \& White, D. (2010). Observations beneath Pine Island Glacier in West Antarctica and implications for its retreat. Nat. Geosci., 3(7), 468-472.

Jenkins, A., \& Jacobs, S. (2008). Circulation and melting beneath George VI ice shelf, Antarctica. J. Geophys. Res, 113, C04013.

Jenkins, A., Shoosmith, D., Dutrieux, P., Jacobs, S., Kim, T. W., Lee, S. H., ... Stammerjohn, S. (2018). West Antarctic ice sheet retreat in the Amundsen Sea driven by decadal oceanic variability. Nature Geoscience, 11(10), 733.

Joughin, I., Alley, R. B., \& Holland, D. M. (2012). Ice-sheet response to oceanic forcing. Science, 338(6111), 1172-1176.

Jourdain, N. C., Mathiot, P., Merino, N., Durand, G., Le Sommer, J., Spence, P., ... Madec, G. (2017). Ocean circulation and sea-ice thinning induced by melting ice shelves in the Amundsen Sea. Journal of Geophysical Research: Oceans, 122(3), 2550-2573.

Kimura, S., Jenkins, A., Dutrieux, P., Forryan, A., Naveira Garabato, A. C., \& Firing, Y. (2016). Ocean mixing beneath Pine Island Glacier ice shelf, West Antarctica. Journal of Geophysical Research: Oceans, 121(12), 8496-8510.

Lumpkin, R., \& Speer, K. (2007). Global ocean meridional overturning. J. Phys. Oceanogr., 37(10), 2550-2562.

Lumpkin, R., Speer, K. G., \& Koltermann, K. P. (2008). Transport across 48 n in the atlantic ocean. Journal of Physical Oceanography, 38(4), 733-752.

Marshall, J., \& Speer, K. (2012). Closure of the meridional overturning circulation through Southern Ocean upwelling. Nat. Geosci., 5(3), 171-180.

Martinson, D. G., Stammerjohn, S. E., Iannuzzi, R. A., Smith, R. C., \& Vernet, M. (2008). Western Antarctic Peninsula physical oceanography and spatiotemporal variability. Deep Sea Res. Pt. II, 55(18), 1964-1987. 
Mathiot, P., Goosse, H., Fichefet, T., Barnier, B., \& Gallée, H. (2011). Modelling the seasonal variability of the Antarctic Slope Current. Ocean Sci., 7(4), 445532 .

Meredith, M. P., \& King, J. C. (2005). Rapid climate change in the ocean west of the antarctic peninsula during the second half of the 20th century. Geophysical Research Letters, 32(19).

Moffat, C., Beardsley, R. C., Owens, B., \& Van Lipzig, N. (2008). A first description of the Antarctic Peninsula Coastal Current. Deep Sea Research Part II: Topical Studies in Oceanography, 55(3-4), 277-293.

Nakayama, Y., Menemenlis, D., Zhang, H., Schodlok, M., \& Rignot, E. Origin of Circumpolar Deep Water intruding onto the Amundsen and Bellingshausen Sea continental shelves. Nature communications, 9(1), 3403.

Nakayama, Y., Timmermann, R., Rodehacke, C. B., Schröder, M., \& Hellmer, H. H. (2014). Modeling the spreading of glacial meltwater from the Amundsen and Bellingshausen Seas. Geophys. Res. Lett., 41.

Naveira Garabato, A., Forryan, A., Dutrieux, P., Brannigan, L., Biddle, L. C., Heywood, K. J., ... Kimura, S. (2017). Vigorous lateral export of the meltwater outflow from beneath an Antarctic ice shelf. Nature, 542(7640), 219.

Nicholls, K. W., Østerhus, S., Makinson, K., Gammelsrød, T., \& Fahrbach, E. (2009). Ice-ocean processes over the continental shelf of the southern Weddell Sea, Antarctica: A review. Reviews of Geophysics, 47(3).

Orsi, A. H., Smethie, W. M., \& Bullister, J. L. (2002). On the total input of Antarctic waters to the deep ocean: A preliminary estimate from chlorofluorocarbon measurements. J. Geophys. Res., 107(C8), 3122.

Orsi, A. H., Whitworth III, T., \& Nowlin Jr, W. D. (1995). On the meridional extent and fronts of the Antarctic Circumpolar Current. Deep Sea Research Part I: Oceanographic Research Papers, 42(5), 641-673.

Paolo, F., Fricker, H., \& Padman, L. (2015). Volume loss from Antarctic ice shelves is accelerating. Science, 348, 327-331.

Pellichero, V., Sallée, J.-B., Schmidtko, S., Roquet, F., \& Charrassin, J.-B. (2017). The ocean mixed layer under Southern Ocean sea-ice: Seasonal cycle and forcing. J. Geophys. Res. Oceans, 122(2), 1608-1633.

Potter, J. R., \& Paren, J. G. (1985). Interaction between ice shelf and ocean in George VI Sound, Antarctica. Oceanology of the Antarctic Continental Shelf, Antarct. Res. Ser, 43, 35-58.

Pritchard, H. D., Ligtenberg, S. R. M., Fricker, H. A., Vaughan, D., Van den Broeke, M. R., \& Padman, L. (2012). Antarctic ice-sheet loss driven by basal melting of ice shelves. Nature, $484(7395), 502-505$.

Purkey, S. G., \& Johnson, G. C. (2013). Antarctic Bottom Water Warming and Freshening: Contributions to Sea Level Rise, Ocean Freshwater Budgets, and Global Heat Gain. J. Climate, 26(16), 6105-6122.

Rignot, E., Jacobs, S., Mouginot, J., \& Scheuchl, B. (2013). Ice-shelf melting around Antarctica. Science, 341(6143), 266-270. Retrieved from http://science .sciencemag. org/content/341/6143/266

Rignot, E., Mouginot, J., Scheuchl, B., van den Broeke, M., van Wessem, M. J., \& Morlighem, M. (2019). Four decades of Antarctic ice sheet mass balance from 1979-2017. Proceedings of the National Academy of Sciences, 116(4), 1095-1103.

Rignot, E., Velicogna, I., Van den Broeke, M. R., Monaghan, A., \& Lenaerts, J. (2011). Acceleration of the contribution of the Greenland and Antarctic ice sheets to sea level rise. Geophys. Res. Lett., 38(5), L05503.

Roach, C. J., \& Speer, K. (2019). Exchange of water between the ross gyre and acc assessed by lagrangian particle tracking. Journal of Geophysical Research: Oceans, 124(7), 4631-4643.

Roquet, F., Wunsch, C., Forget, G., Heimbach, P., Guinet, C., Reverdin, G., ... oth- 
ers (2013). Estimates of the Southern Ocean general circulation improved by animal-borne instruments. Geophysical Research Letters, 40(23), 6176-6180.

Schaffer, J., \& Timmermann, R. (2016). Greenland and Antarctic ice sheet topography, cavity geometry, and global bathymetry (RTopo-2), links to NetCDF files. PANGAEA.

Schodlok, M. P., Menemenlis, D., Rignot, E., \& Studinger, M. (2012). Sensitivity of the ice-shelf/ocean system to the sub-ice-shelf cavity shape measured by NASA IceBridge in Pine Island Glacier, West Antarctica. Annals of Glaciology, 53(60), 156-162.

Schoof, C. (2007). Ice sheet grounding line dynamics: Steady states, stability, and hysteresis. J. Geophys. Res, 112(10.1029).

Schulze Chretien, L., Thompson, A., Flexas, M., Speer, K., Swaim, N., Oelerich, R., ... R. Schubert, C. L. (2021). The shelf circulation of the Bellingshausen Sea. J. Geophys. Res. Oceans, in press. doi: 10.1029/2020JC016871

Shepherd, A., Wingham, D., \& Rignot, E. (2004). Warm ocean is eroding West Antarctic ice sheet. Geophys. Res. Lett., 31 (23), L23404.

Smith, B., Fricker, H. A., Gardner, A. S., Medley, B., Nilsson, J., Paolo, F. S., ... others (2020). Pervasive ice sheet mass loss reflects competing ocean and atmosphere processes. Science, 368(6496), 1239-1242.

Smith, D. A., Hofmann, E. E., Klinck, J. M., \& Lascara, C. M. (1999). Hydrography and circulation of the West Antarctic Peninsula continental shelf. Deep Sea Res. Pt. I, 46(6), 925-950.

Smith, R. C., Baker, K. S., Fraser, W. R., Hofmann, E. E., Karl, D. M., Klinck, J. M., ... others (1995). The palmer lter: A long-term ecological research program at palmer station, antarctica. Oceanography, 8(3), 77-86.

Steig, E. J., Ding, Q., Battisti, D. S., \& Jenkins, A. (2012). Tropical forcing of Circumpolar Deep Water Inflow and outlet glacier thinning in the Amundsen Sea Embayment, West Antarctica. Ann. Glaciol., 53(60), 19-28.

Talbot, M. H. (1988). Oceanic environment of George VI ice shelf, Antarctic Peninsula. Ann. Glaciol., 11, 161-164.

Talley, L. D. (2013). Closure of the global overturning circulation through the Indian, Pacific, and Southern Oceans: Schematics and transports. Oceanography, 26(1), 80-97.

Thoma, M., Jenkins, A., Holland, D., \& Jacobs, S. (2008). Modelling circumpolar deep water intrusions on the Amundsen Sea continental shelf, Antarctica. Geophys. Res. Lett., 35(18).

Thomas, R. H., \& Bentley, C. R. (1978). A model for holocene retreat of the west antarctic ice sheet. Quaternary Research, 10(2), 150-170.

Thompson, A. F., Speer, K. G., \& Schulze Chretien, L. M. (2020). Genesis of the antarctic slope current in west antarctica. Geophysical Research Letters, 47(16), e2020GL087802.

Thurnherr, A. M., Jacobs, S. S., Dutrieux, P., \& Giulivi, C. F. (2014). Export and circulation of ice cavity water in Pine Island Bay, West Antarctica. J. Geophys. Res., 119(3), 1754-1764.

Venables, H. J., Meredith, M. P., \& Brearley, J. A. (2017). Modification of deep waters in Marguerite Bay, western Antarctic Peninsula, caused by topographic overflows. Deep Sea Research Part II: Topical Studies in Oceanography, 139, $9-17$.

Webber, B. G., Heywood, K. J., Stevens, D. P., \& Assmann, K. M. (2019). The impact of overturning and horizontal circulation in Pine Island Trough on ice shelf melt in the eastern Amundsen Sea. Journal of Physical Oceanography, 49(1), 63-83.

Webber, B. G., Heywood, K. J., Stevens, D. P., Dutrieux, P., Abrahamsen, E. P., Jenkins, A., ... Kim, T. W. (2017). Mechanisms driving variability in the ocean forcing of Pine Island Glacier. Nature communications, 8, 14507. 
Weertman, J. (1974). Stability of the junction of an ice sheet and an ice shelf. Journal of Glaciology, 13(67), 3-11.

Whitworth, T., Orsi, A. H., Kim, S.-J., Nowlin, W. D., \& Locarnini, R. A. (1998). Water masses and mixing near the Antarctic Slope Front. Ocean, ice, and atmosphere: interactions at the Antarctic continental margin, 1-27.

Wunsch, C. (1978). The North Atlantic general circulation west of $50 \mathrm{~W}$ determined by inverse methods. Reviews of Geophysics, 16(4), 583-620.

Wunsch, C., Hu, D., \& Grant, B. (1983). Mass, heat, salt and nutrient fluxes in the south pacific ocean. Journal of Physical Oceanography, 13(5), 725-753.

Zhang, X., Thompson, A. F., Flexas, M. M., Roquet, F., \& Bornemann, H. (2016). Circulation and meltwater distribution in the Bellingshausen Sea: From shelf break to coast. Geophysical Research Letters, 43(12), 6402-6409. 